\title{
Relative importance of black carbon, brown carbon, and absorption enhancement from clear coatings in biomass burning emissions
}

\author{
Rudra P. Pokhrel ${ }^{1}$, Eric R. Beamesderfer ${ }^{1, a}$, Nick L. Wagner ${ }^{2}$, Justin M. Langridge ${ }^{3}$, Daniel A. Lack ${ }^{4}$, \\ Thilina Jayarathne $^{5}$, Elizabeth A. Stone ${ }^{5}$, Chelsea E. Stockwell ${ }^{6}$, Robert J. Yokelson ${ }^{6}$, and Shane M. Murphy ${ }^{1}$ \\ ${ }^{1}$ Department of Atmospheric Science, University of Wyoming, Laramie, Wyoming, USA \\ ${ }^{2}$ NOAA Earth System Research Laboratory, Chemical Sciences Division, Boulder, Colorado, USA \\ ${ }^{3}$ Observation Based Research, Met Office, Fitzroy Road, Exeter, EX1 3PB, UK \\ ${ }^{4}$ Transport Emissions, Air Quality and Climate Consulting, Brisbane, Australia \\ ${ }^{5}$ Department of Chemistry, University of Iowa, Iowa City, Iowa, USA \\ ${ }^{6}$ Department of Chemistry, University of Montana, Missoula, Montana, USA \\ ${ }^{a}$ now at: School of Geography and Earth Science, McMaster University, Hamilton, Ontario, Canada
}

Correspondence to: Rudra P. Pokhrel (rpokhrel@uwyo.edu) and Shane M. Murphy (shane.murphy@uwyo.edu)

Received: 12 November 2016 - Discussion started: 18 November 2016

Revised: 25 February 2017 - Accepted: 22 March 2017 - Published: 19 April 2017

\begin{abstract}
A wide range of globally significant biomass fuels were burned during the fourth Fire Lab at Missoula Experiment (FLAME-4). A multi-channel photoacoustic absorption spectrometer (PAS) measured dry absorption at 405, 532, and $660 \mathrm{~nm}$ and thermally denuded $\left(250^{\circ} \mathrm{C}\right)$ absorption at 405 and $660 \mathrm{~nm}$. Absorption coefficients were broken into contributions from black carbon (BC), brown carbon $(\mathrm{BrC})$, and lensing following three different methodologies, with one extreme being a method that assumes the thermal denuder effectively removes organics and the other extreme being a method based on the assumption that black carbon (BC) has an Ångström exponent of unity. The methodologies employed provide ranges of potential importance of $\mathrm{BrC}$ to absorption but, on average, there was a difference of a factor of 2 in the ratio of the fraction of absorption attributable to $\mathrm{BrC}$ estimated by the two methods. $\mathrm{BrC}$ absorption at shorter visible wavelengths is of equal or greater importance to that of BC, with maximum contributions of up to $92 \%$ of total aerosol absorption at $405 \mathrm{~nm}$ and up to $58 \%$ of total absorption at $532 \mathrm{~nm}$. Lensing is estimated to contribute a maximum of $30 \%$ of total absorption, but typically contributes much less than this. Absorption enhancements and the estimated fraction of absorption from $\mathrm{BrC}$ show good correlation with the elemental-carbon-to-organic-carbon ratio (EC / OC) of emitted aerosols and weaker correlation with the modified combustion efficiency (MCE). Previous studies have shown
\end{abstract}

that $\mathrm{BrC}$ grows darker (larger imaginary refractive index) as the ratio of black to organic aerosol (OA) mass increases. This study is consistent with those findings but also demonstrates that the fraction of total absorption attributable to $\mathrm{BrC}$ shows the opposite trend: increasing as the organic fraction of aerosol emissions increases and the EC/OC ratio decreases.

\section{Introduction}

The significant impact of black carbon (BC) aerosol on radiative forcing is well established (Bond et al., 2013), but the magnitude and wavelength dependence of absorption by organic carbon (often called brown carbon, $\mathrm{BrC}$ ) remains poorly constrained (Barnard et al., 2008; Lack et al., 2012a; Kirchstetter and Thatcher, 2012; Bahadur et al., 2012; McMeeking et al., 2014; Laskin et al., 2015; Olson et al., 2015). If BC is coated by non-absorbing organics (primary or secondary organic aerosol) or inorganic non-absorbing materials (ammonium sulfate, ammonium nitrate, etc.) these coatings can enhance the magnitude of absorption by the $\mathrm{BC}$ core. This effect is often called, somewhat inaccurately, lensing, and for simplicity this term will be utilized in this paper (Fuller et al., 1999). The lensing effect is slightly decreased if the coatings themselves are absorbing (Lack and Cappa, 
2010). While Mie calculations and lab studies support the notion that significant (50-100\%) increases in BC absorption can occur via lensing at atmospherically relevant aerosol sizes, observations of this effect in ambient air have yielded a wide range of results (Bond et al., 2006; Cappa et al., 2012; Nakayama et al., 2014). Studies have also found a wide range of possible imaginary refractive indices for $\mathrm{BrC}$ (Kirchstetter et al., 2004; Lack et al., 2012a; Alexander et al., 2008; Saleh et al., 2014), with Saleh et al. (2014) postulating that the imaginary refractive index can be predicted if the ratio of black carbon to organic aerosol mass (BC: OA) is known.

Potential sources of $\mathrm{BrC}$ include emissions from biomass burning (Kirchstetter et al., 2004; Moosmüller et al., 2009; Chen and Bond, 2010; Lack et al., 2012a; Saleh et al., 2014; Washenfelder et al., 2015); incomplete combustion of fossil fuels, especially coal (Bond, 2001; Yang et al., 2009; Olson et al., 2015); and secondary organic aerosols (Saleh et al., 2013; Zhang et al., 2013; Liu et al., 2014; Lin et al., 2015). There exists significant uncertainty concerning the relative contribution of each of these source types to total $\mathrm{BrC}$ concentrations, but several studies have identified biomass burning as a potentially significant source (Washenfelder et al., 2015; McMeeking et al., 2014; Lack et al., 2012a). Open biomass burning (BB) is one of the largest global sources of $\mathrm{BC}$ and organic carbon (OC), and biomass burning emissions have a significant direct effect on the Earth's radiative balance (Bond et al., 2013). When biomass burning emissions interact with clouds, there are significant semi-direct and indirect effects, and the magnitude of the semi-direct effects depends on the optical properties of the emitted aerosols (Sakaeda et al., 2011; Lin et al., 2014; Jacobson, 2014).

Absorption enhancement can be defined as the ratio of the absorption of ambient aerosol (with coatings present) to the absorption of $\mathrm{BC}$ alone. Experimental attempts to quantify absorption enhancement often employ thermal denuders to remove organic and inorganic coatings. Lack et al. (2012a) measured ambient aerosols with a large influence of biomass burning and found absorption enhancements up to 2.5 at $405 \mathrm{~nm}$ and 1.4 at $532 \mathrm{~nm}$ using a thermal denuder. Laboratory measurements of absorption enhancement in biomass burning aerosols show significant variation with values greater than 2 observed at $405 \mathrm{~nm}$ in some samples and values ranging from 1.2 to 1.5 at 532 and $781 \mathrm{~nm}$ (McMeeking et al., 2014). There are a number of studies that estimate the absorption due to $\mathrm{BrC}$ in the blue and ultraviolet wavelengths (Yuan et al., 2016; Washenfelder et al., 2015; Guo et al., 2014; Nakayama et al., 2014; Lack et al., 2012a; Cappa et al., 2012; Bahadur et al., 2012; Flowers et al., 2010; Wang et al., 2016; Stockwell et al., 2016). Results from these studies show large variations in the estimated percentage of absorption attributable to BrC. Laboratory and field studies have measured wide ranges of $\mathrm{BrC}$ absorptivity values (Kirchstetter et al., 2004; Lack et al., 2012a; Alexander et al., 2008; Saleh et al., 2014). Recent model studies have shown that inclusion of $\mathrm{BrC}$ could significantly alter the direct radia- tive forcing due to carbonaceous aerosols (Saleh et al., 2015; Feng et al., 2013). Additionally, $\mathrm{BrC}$ is thought to lose its absorptivity in a relatively short (hours to days) amount of time aging in the atmosphere (Wang et al., 2016; Forrister et al., 2015; Lee et al., 2014). This aging provides another reason it is critical to differentiate between absorption from $\mathrm{BrC}$ and BC.

To understand the relative importance of absorption from $\mathrm{BrC}$ vs. lensing and $\mathrm{BC}$, it is critical to understand the potential variability in attribution of absorption caused by different methodologies. Various studies show large variations in the percentage of absorption due to $\mathrm{BrC}$ (Yuan et al., 2016; Washenfelder et al., 2015; Guo et al., 2014; Nakayama et al., 2014; Lack et al., 2012a; Cappa et al., 2012; Bahadur et al., 2012; Flowers et al., 2010) at blue wavelengths. While some of the variation is certainly due to variations in the ambient aerosol, some could potentially be the result of various approaches used to estimate the contribution of $\mathrm{BrC}$ to total light absorption in previous studies. Lack et al. (2012a) and Saleh et al. (2014) used core-shell Mie theory with inputs of $\mathrm{BC}$ core and shell size and the imaginary refractive index of BrC. Particle morphology is also taken in account, using the Rayleigh-Debye-Gans approximation, in some studies (Liu et al., 2015). Others have used the difference in absorption enhancement from thermally denuding the aerosol at different wavelengths to determine the contribution from evaporated $\mathrm{BrC}$ (Guo et al., 2014; Nakayama et al., 2014; Cappa et al., 2012), with the assumption that the lensing effect depends weakly on wavelength (Lack and Cappa, 2010). Another method that is simple and widely applied assumes an absorption Ångström exponent (AAE) value for BC (typically 1) and defines absorption above the predicted $\mathrm{BC}$ absorption at low wavelengths to be $\mathrm{BrC}$, while sometimes also accounting for lensing (Fialho et al., 2005; Favez et al., 2009; Bahadur et al., 2012; Cazorla et al., 2013; Yuan et al., 2016). In this study, we estimate the percentage of absorption due to $\mathrm{BC}$, lensing, and $\mathrm{BrC}$ following methodologies based on assuming an AAE and based on thermally denuding the aerosol, thereby providing a range that covers variations caused by experimental approach, of potential contributions to absorption in biomass burning emissions from $\mathrm{BrC}$, lensing and $\mathrm{BC}$.

Recent studies have shown that certain parameters can be used to parameterize biomass burning aerosol optical properties. These parameters include modified combustion efficiency (MCE), black carbon to organic aerosol ratio $(\mathrm{BC} / \mathrm{OA})$, and elemental to total carbon ratio $\left(\frac{\mathrm{EC}}{\mathrm{EC}+\mathrm{OC}}\right)$ (Pokhrel et al., 2016; Lu et al., 2015; Saleh et al., 2014; McMeeking et al., 2014; Liu et al., 2014). The current study demonstrates that the magnitude of total $\mathrm{BrC}$ absorption can be parameterized with the EC / OC ratio, a distinct result from Saleh et al. (2014) who demonstrated that the intensive quantity of absorptivity, or imaginary refractive index, can be parameterized with the $\mathrm{BC} / \mathrm{OA}$ ratio. 


\section{Materials and methods}

Measurements were made during the multi-investigator FLAME-4 experiment. Details of the fuels burned and overall experiment can be found in Stockwell et al. (2014), and details of the experimental setup for optical measurements in Pokhrel et al. (2016). The schematic of the instrumental setup during the FLAME-4 experiment is shown in Fig. 1. Briefly, this study reports results from 12 different fuels with significant global emissions over 22 individual burns, as detailed in Fig. 4. All results presented are from burns where a fire was ignited in a large combustion room at the Missoula Fire Sciences Laboratory and allowed to burn to completion. Measurements were made after smoldering had ceased and emissions from all stages of the fire had become well mixed in the combustion room.

\subsection{Inlet system}

Aerosol was pulled from an inlet placed roughly $3 \mathrm{~m}$ above the floor of a $12.5 \mathrm{~m} \times 12.5 \mathrm{~m} \times 22 \mathrm{~m}$ combustion room once the smoke was well mixed (typically 15-20 min after the start of a burn). Fuels burned include ponderosa pine, black spruce, rice straw, organic hay, organic and conventional wheat, sugarcane, giant cut saw grass, wire grass, African grass, chamise, manzanita, and North Carolina peat. Smoke was transferred to the instruments at $10 \mathrm{~L} \mathrm{~min}^{-1}$ through a 0.5 inch outside diameter (OD) copper line. Aerosol was passed through a cyclone impactor that removed particles with aerodynamic diameters larger than $2.5 \mu \mathrm{m}$ and diluted with particle-free air in order to maintain extinction levels near $500 \mathrm{Mm}^{-1}$ to avoid saturation of sampling instrumentation. It is important to note that aerosol sampled for EC / OC measurements (Sect. 2.7) was not diluted. Next, the air was dried by two 100-tube Nafion driers (Perma Pure, Toms River, NJ, USA) operated in parallel, which reduced the relative humidity in the sample cell to less than $15 \%$. Following the Nafion driers, an activated carbon monolith (MAST Carbon, Basingstoke, UK) was used to scrub $\mathrm{NO}_{x}$ and $\mathrm{O}_{3}$ from the sample air while transmitting the particles. The successful removal of $\mathrm{NO}_{x}$ was continuously tracked by a cavity ring-down spectrometer (CRDS) gas-phase channel at $405 \mathrm{~nm}$. A filter was periodically inserted (at an interval of 5 to $10 \mathrm{~min}$ ) into the sample stream to remove particles and confirm baseline stability.

\subsection{Instrumentation}

Aerosol absorption measurements were made with a multiwavelength photoacoustic absorption spectrometer (PAS) instrument (Lack et al., 2006; 2012b). The PAS was configured with five cells that measured absorption coefficients of dry aerosol $(\mathrm{RH}<15 \%)$ at 405,532 , and $660 \mathrm{~nm}$ and denuded aerosol at 405 and $660 \mathrm{~nm}$. An integral component of the PAS was a thermal denuder system. The thermal de-

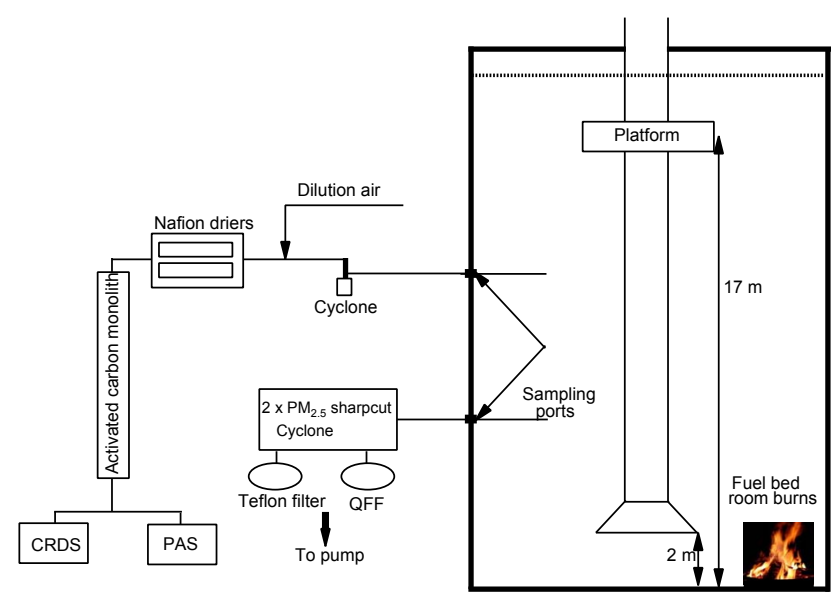

Figure 1. The schematic of instrumental setup during the FLAME-4 experiment.

nuder deployed during FLAME-4 was a $50 \mathrm{~cm}$ long, $1.1 \mathrm{~cm}$ inside diameter (ID) stainless steel tube heated to $250^{\circ} \mathrm{C}$ followed by a $50 \mathrm{~cm} 0.43 \mathrm{in}$. ID unheated tube with an activated carbon honeycomb monolith (MAST Carbon, Basingstoke, UK). The denuder was run at $250^{\circ} \mathrm{C}$ in an attempt to avoid charring of organic aerosol which would artificially increase absorbing material in the denuded channel. The flow rate through the thermal denuder was $5 \mathrm{~L} \mathrm{~min}^{-1}$. The activated carbon section absorbed volatile species that evaporate from the aerosol in the heated region. This denuder configuration was shown to have almost complete removal of a semivolatile organic compound (di-ethyl-hexyl-sebacate having a boiling point of $300^{\circ} \mathrm{C}$ ) coating sodium chloride cores (Fierz et al., 2007). It is known that biomass burning emissions often have low-volatility material and these materials can be absorbing (May et al., 2013; Saleh et al., 2014). It is possible, in fact probable given that the denuder was run at $250{ }^{\circ} \mathrm{C}$ to avoid charring, that all of the absorbing organic material was not removed by the thermal denuder in this study, which will be discussed in detail in the results and discussion.

\subsection{PAS calibration}

A CRDS (Langridge et al., 2011) that operates at identical wavelengths to the PAS $(660,532,405 \mathrm{~nm})$ was used to calibrate PAS absorption measurements. Calibrations were conducted using ozone sampled simultaneously by the PAS and CRDS. PAS absorption at a given wavelength was set equal to the measured extinction from the CRDS at that same wavelength, with Rayleigh scattering subtracted. Further details of the PAS calibration using the CRDS can be found in Lack et al. (2012b). Further details about the instrumental setup of the PAS and CRDS can be found in Pokhrel et al. (2016). The uncertainty associated with the PAS measurements during FLAME-4 was found to be $7 \%(1 \sigma)$ in the 660 and $532 \mathrm{~nm}$ channels and $18 \%(1 \sigma)$ in the $405 \mathrm{~nm}$ 


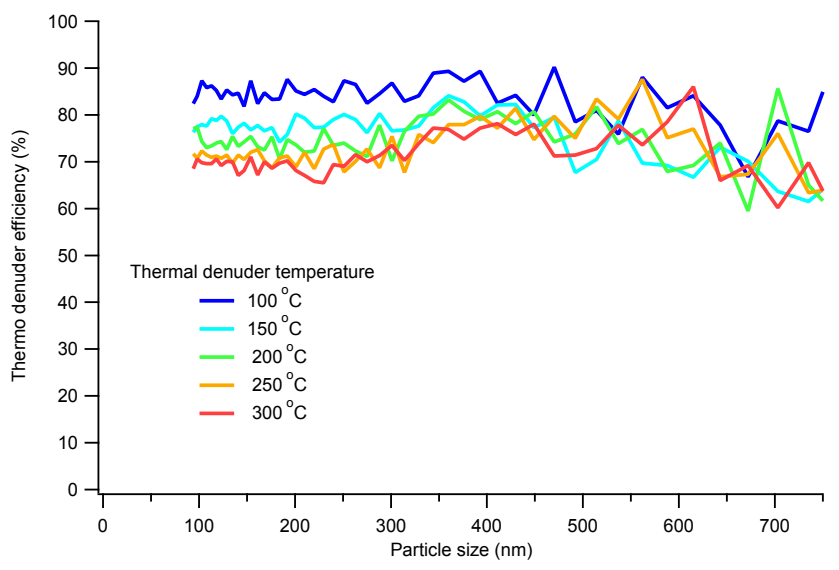

Figure 2. Particles loss through the thermal denuder as a function of particle size and thermal denuder temperature.

channel (Pokhrel et al., 2016). The higher uncertainty in the $405 \mathrm{~nm}$ channel is due to the use of ozone during PAS calibration. The absorption cross section of ozone at $405 \mathrm{~nm}$ is $1.51 \times 10^{-23} \mathrm{~cm}^{2}$ molecule ${ }^{-1}$ (Axson et al., 2011), which is 2 orders of magnitude less than the absorption cross section in the $450-858 \mathrm{~nm}$ range $\left(10^{-21} \mathrm{~cm}^{2}\right.$ molecule $\left.^{-1}\right)$ (Anderson and Mauersberg, 1992). During ozone calibration, the absorption coefficients at $405 \mathrm{~nm}$ were always less than $20 \mathrm{Mm}^{-1}$, which resulted in a calibration curve with significantly more uncertainty than the curves for the other wavelengths when extrapolated to the high absorption values observed in this study.

\subsection{Particles loss in thermal denuder}

Particle losses occur inside the thermal denuder because of thermophoretic and diffusional processes (Wehner et al., 2002). Particle loss in the thermal denuder was measured by passing glassy carbon spheres through the denuder at a flow rate of $5 \mathrm{~L} \mathrm{Min}^{-1}$. Different-sized particles were passed through the thermal denuder at multiple temperatures. Figure 2 shows the percentage of particles that were transmitted through the thermal denuder. The percentage of particles lost in the thermal denuder depends on both particle size and thermal denuder temperature. During FLAME-4, the vast majority of particles for all burns were less than $300 \mathrm{~nm}$ (Saleh et al., 2014) and the temperature of the thermal denuder was set to $250^{\circ} \mathrm{C}$. Under these conditions, the transmission efficiency of the thermal denuder is $71 \%$ on average. Based on this, denuded absorption was divided by 0.71 to correct for losses. It is important to note that this size range and temperature result in nearly the maximal particle loss through the denuder, observed in Fig. 2, and it is therefore possible that particle losses through the denuder could be overcorrected. If this occurs, it will lead to an underestimate of absorption enhancement in particles. The efficiency curves are relatively insensitive to diameter, making it a reasonable
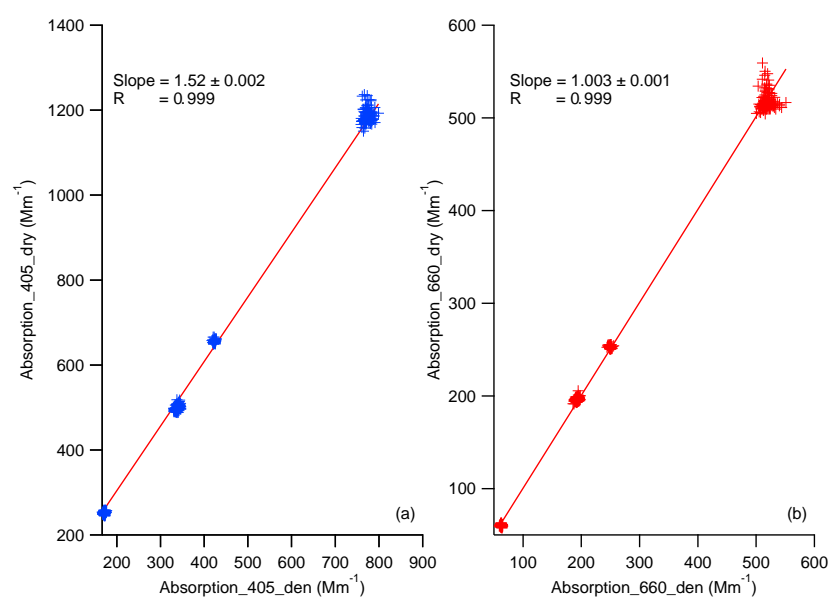

Figure 3. Comparison of absorption coefficients measured by dry and denuded channels during thermal denuder bypasses for a day with significant differences in the $405 \mathrm{~nm}$ channel. (a) $405 \mathrm{~nm}$, (b) $660 \mathrm{~nm}$.

assumption to have a fixed efficiency factor and not have to consider complications associated with particle size, and thus transmission efficiency, changing as the particle evaporates on passing through the denuder. Absorption enhancements based on the thermal denuder measurements as low as 0.91 were observed during the FLAME-4 study, suggesting denuder losses were overcorrected by $10 \%$ in some cases. Because this error is larger than what would be expected based on Fig. 2, we used these in situ observations to justify the application of a $\pm 10 \%$ uncertainty to our denuder-derived $a b$ sorption enhancements due to uncertainty in particle losses (see Sect. 2.5 for details).

Because absorption enhancements derived from thermally denuded channels in this study were obtained by comparing denuded and dry channels at the same wavelength run in parallel, it was critical to ensure that both the dry and denuded channels at a given wavelength gave nearly identical absorption coefficients when the denuder was not inline. To verify this, numerous thermal denuder bypasses were completed with the purpose of ensuring that enhanced absorption observed in dry channels was caused by coatings and not by instrumental drift of other issues. During a thermal denuder bypass, inlet air was diverted around the thermal denuder and directly to the cell that normally measured denuded aerosol. Several thermal denuder bypasses were done during each day and the absorption coefficients measured by the dry and denuded channels were compared when measuring identical input aerosol. Figure 3 below shows a comparison of absorption coefficients for dry and denuded channels measured during thermal denuder bypasses. For $660 \mathrm{~nm}$ the slope between the absorption coefficients measured by the dry and denuded channels is within $3 \%$ of unity. However, at $405 \mathrm{~nm}$, the two channels differ by as much as $52 \%$ (a day with one of the largest observed differences is shown). 
This difference is largely due to the relatively large $(18 \%$, $1 \sigma$ ) error in the calibration of the $405 \mathrm{~nm}$ channel, but is still at the outer limits of the Gaussian error curve created when the errors are added in quadrature. The idea that the large differences between the channels are more than random error is supported by the observation that the dry channel was found to be consistently higher than the denuded channel. The very high correlation ( $R$ above 0.99$)$ between the denuded and dry channels gives confidence that this is an error in the absolute calibrations of the channels and that the magnitude of the instrument response through the day is consistent between the two channels. The reason for the denuded $405 \mathrm{~nm}$ channel having consistently lower signal than the dry $405 \mathrm{~nm}$ channel remains unclear. However, during the last 3 days of experimentation, new critical orifices were added to the ozone calibration system allowing the introduction of higher levels of ozone. The calibration of the dry $405 \mathrm{~nm}$ channel determined without the high ozone points (what was done for most of the project) was consistently closer to the slope determined using all ozone concentrations (including the high ozone points) than the calibration of the denuded $405 \mathrm{~nm}$ channel without the high-ozone points. These results suggest that the dry channel calibrations were more accurate than the denuded channel calibrations, and because of this the denuded channel absorption was adjusted to match the dry channel absorption. The adjustment factors for each day of measurement are provided in Table S1 in the Supplement.

\subsection{Absorption enhancement and absorption Ångström exponent}

Absorption enhancement is defined here as the amount of absorption observed when all material is present (BC and coatings) vs. the absorption observed when just $\mathrm{BC}$ is present. One way to estimate absorption enhancement is to measure the absorption of particles that have been thermally denuded at a temperature high enough to remove organics vs. the absorption from unperturbed particles (Lack et al., 2012a):

$E_{\text {AbsDen }}=\frac{b_{\text {abs_dry }(\lambda)}}{b_{\text {abs_den }(\lambda)}}$,

where $b_{\text {abs_dry }(\lambda)}$ is the absorption coefficient of ambient particles at a specific wavelength and $b_{\text {abs_den }(\lambda)}$ is he absorption coefficient at the same wavelength after the particles are heated in a thermal denuder. The thermal denuder in this experiment was run at $250^{\circ} \mathrm{C}$. The error in the $E_{\text {AbsDen }}$ calculated in this way does not depend on the absolute accuracy of either the dry or the denuded absorption, because denuded absorption was adjusted to match the dry absorption during thermal denuder bypasses, and while the corrections can be large they were very stable throughout a given day (Fig. 3). Instead, the dominant errors in this calculation are the possibility that the denuder does not remove all organics and the need to adjust for particle losses in the denuder. The minimum value of $E_{\mathrm{AbsDen}}$ calculated in this study was $\sim 0.91$, observed during measurements of a fire with a very high MCE and presumably very little non-BC material being emitted. This result is only possible if particle loss in the thermal denuder is overcorrected, and based on this we derive the error in $E_{\mathrm{AbsDen}}$ due to particle loss corrections to be $\pm 10 \%$ and add this uncertainty in quadrature to 1 standard deviation of the average measured value to report the total uncertainty in the $E_{\mathrm{Abs} D e n}$. This total error does not account for the potential error of not fully removing organics in the denuder, since this error cannot be quantified. AAE is defined as $b_{\mathrm{abs}}=a \lambda^{-\mathrm{AAE}}$ where $b_{\mathrm{abs}}$ is the absorption coefficient and the constant, $a$, is independent of wavelength. AAE is estimated from the slope of least-square fit of the logarithm of absorption coefficients vs. the logarithm of wavelengths. AAE are determined from the three wavelengths $(405,532$, and $660 \mathrm{~nm}$ ).

\subsection{Modified combustion efficiency (MCE)}

The MCE is defined as follows (Ward and Radke, 1993; Yokelson et al., 1997):

$\mathrm{MCE}=\frac{\Delta \mathrm{CO}_{2}}{\Delta \mathrm{CO}+\Delta \mathrm{CO}_{2}}$,

where $\triangle \mathrm{CO}$ and $\Delta \mathrm{CO}_{2}$ are the mixing ratio enhancements above background. Background mixing ratios were measured before the ignition of each burn. The $\mathrm{CO}$ and $\mathrm{CO}_{2}$ mixing ratios were measured by an open-path Fourier transform infrared spectrometer (Stockwell et al., 2014). The MCE reported in this study is the fire-integrated value.

\subsection{Determination of elemental carbon to organic carbon ratio (EC / OC)}

EC / OC estimates were made in identical fashion to Pokhrel et al. (2016), but are described here again for clarity. Fine particulate matter $\left(\mathrm{PM}_{2.5}\right)$ was selected by a cyclone operating at a flow rate of $42 \mathrm{~L} \mathrm{~min}^{-1}$ and was collected on to $37 \mathrm{~mm}$ quartz fiber filters (QFF; PALL, Port Washington, NY) at ambient temperature. Field blanks were collected at a rate of one in seven samples. Prior to use, QFF were precleaned by baking at $550^{\circ} \mathrm{C}$ for $18 \mathrm{~h}$. Filters were stored in cleaned aluminum-foil-lined Petri dishes sealed with Teflon tape, and stored frozen $\left(-20^{\circ} \mathrm{C}\right)$ before and after analysis. OC and EC were measured by thermal optical analysis (Sunset Laboratories, Forest Grove, OR, USA) following the IMPROVE-A protocol where the EC / OC split was determined by thermal optical transmittance. The effects of positive sampling artifacts due to carbonaceous gas adsorption were assessed using quartz filters behind Teflon (QBT; Cheng et al., 2009) for 14 of the 96 fires, including grass, rice straw, ponderosa pine, black spruce, and peat. For fires with QBT collected, the OC on the backup filter was subtracted directly. For fires without backup filters or those that were below the detection limit, the average OC correction 
for that fuel type was applied: rice straw $(2.0 \pm 0.4 \%)$, ponderosa pine $(1.2 \%)$, black spruce $(2.9 \pm 1.6 \%)$, and peat $(3.1 \pm 0.8 \%)$. For fuel types without backup filters collected, the study average OC artifact $(2.4 \pm 1.2 \%)$ was subtracted. This approach to artifact correction assumes that the amount of carbonaceous gas adsorbed is proportional to the mass concentration of $\mathrm{OC}$; this assumption is considered to be reasonable because the back-up filters contained less than $5.6 \mu \mathrm{g} \mathrm{OC} \mathrm{cm}^{-2}$ and similar quartz fiber filters become saturated above $6 \mu \mathrm{g} \mathrm{OC} \mathrm{cm}^{-2}$ (Turpin et al., 1994). Analytical uncertainties for $\mathrm{OC}$ were propagated from the standard deviation of field blanks $\left(0.7 \mu \mathrm{g} \mathrm{cm}^{-2}\right)$ and $5 \%$ of the OC concentration. For EC, uncertainties were propagated from an estimate of the instrument precision $\left(0.1 \mu \mathrm{g} \mathrm{m}^{-2}\right), 5 \%$ of EC concentration and $5 \%$ of pyrolyzed carbon (which forms from OC charring on the filter during analysis). The value of $5 \%$ is a conservative estimate of the precision error in replicate sample analysis, which is typically $1-3 \%$ (NIOSH, 1999). Analytical uncertainties for the EC / OC ratio were propagated from the individual EC and OC uncertainties.

\section{Results and discussion}

\subsection{Absorption enhancement derived with a thermal denuder}

Absorption enhancement determined by comparing aerosol passed through a thermal denuder at $250{ }^{\circ} \mathrm{C}$ to nonthermally-denuded aerosol ( $\left.E_{\mathrm{AbsDen}}, \mathrm{Eq} .1\right)$ was calculated during 22 individual burns of 12 different fuels. The $E_{\mathrm{AbsDen}}$ values reported in this study are the average value obtained over approximately $1 \mathrm{~h}$ of measurements that were made after the smoke had completely mixed in the combustion room. Figure 4 shows bar plots of the average $E_{\mathrm{AbsDen}}$ for different fuels. Repeated burns of the same fuel often generated different burn conditions resulting in different MCEs (Eq. 2), which are also given. The total bar height (red plus blue) represents the absorption enhancement at $405 \mathrm{~nm}$ and red bars represent $E_{\text {absDen }}$ at $660 \mathrm{~nm}$. Fuels are categorized into four different groups: coniferous trees, crop residues, grasses and brushwood, and peat. These fuel categories have large contributions to the total biomass burning across different parts of world (Page et al., 2002; Chang and Song, 2010; Clinton et al., 2006; McCarty et al., 2007). For all burns, $E_{\text {AbsDen }}$ is larger at $405 \mathrm{~nm}$ than at $660 \mathrm{~nm}$, except for a giant saw grass (GSG) burn where the two are nearly identical. In this burn, both the 405 and $660 \mathrm{~nm} E_{\mathrm{Abs} \text { Den }}$ are unity within experimental uncertainty, suggesting that the $\mathrm{BC}$ emitted during this burn had very little coating. The fact that all burns, except giant saw grass and wire grass, have an $E_{\mathrm{AbsDen}}$ at $405 \mathrm{~nm}$ significantly larger than that at $660 \mathrm{~nm}$ provides evidence of the presence of $\mathrm{BrC}$ on most of the burns since the lensing effect typically has a weak dependence on wavelength (Lack and Cappa, 2010; McMeeking et al., 2014).
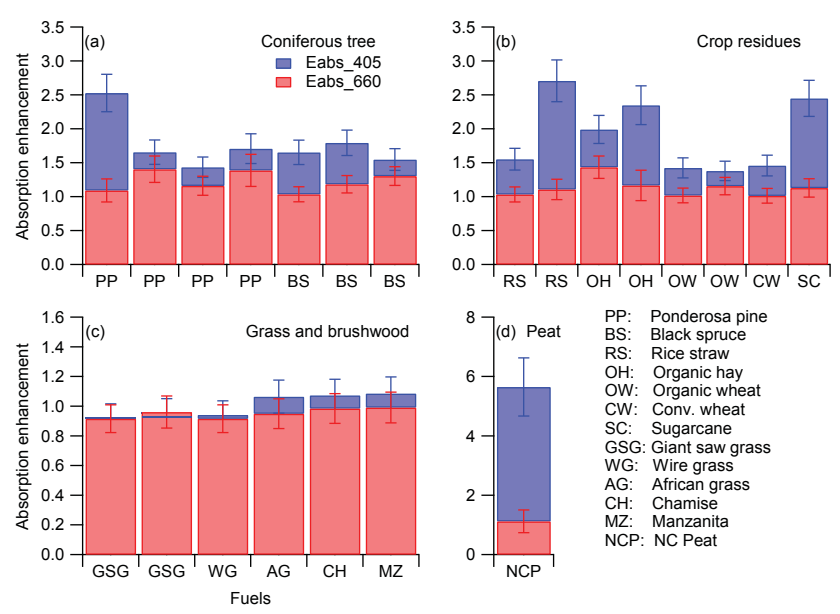

PP: Ponderosa pine
BS: Black spruce

BS: Black spruce

OH: Organic hay

OW: Organic wheat

$\mathrm{CW}$ : Conv. wheat

SC: Sugarcane

WG: Wire grass

AG: African gras
$\mathrm{CH}:$ Chamise

MZ: Manzanita

NCP: NC Peat

Figure 4. Bar plots of absorption enhancements derived by thermally denuding aerosol and measuring denuded and non-denuded particles at both 405 and $660 \mathrm{~nm}$. Results are grouped in terms of fuel types. Total bar heights (red + blue) are representative of absorption enhancement at $405 \mathrm{~nm}$ while red bars represent absorption enhancement at $660 \mathrm{~nm}$. Panel (a) is for coniferous trees, (b) is for crop residues, (c) is for grass and brushwood, and (d) is for peat. The legend shows the name of each fuels reported in each group.

$E_{\text {AbsDen }}$ at $660 \mathrm{~nm}$ ranges from $0.92 \pm 0.09$ to $1.43 \pm 0.17$, similar to the range of $E_{\text {AbsDen }}$ observed during FLAME-3 for a different suite of fuels. FLAME-3 $E_{\text {AbsDen }}$ results at 532 and $781 \mathrm{~nm}$ ranged from 1.2 to 1.5 (McMeeking et al., 2014) but the thermal denuder in that study was operated at or below $150{ }^{\circ} \mathrm{C}$ while the thermal denuder in this study was run at $250^{\circ} \mathrm{C}$. Our results at $660 \mathrm{~nm}$ are also similar to the $E_{\mathrm{Abs}}$ of 1.4 measured at $532 \mathrm{~nm}$ in a biomass plume near Boulder, CO, USA (Lack et al., 2012a). The range of $E_{\text {AbsDen }}$ at $405 \mathrm{~nm}$ observed in this study is similar to previous studies (McMeeking et al., 2014; Lack et al., 2012a), except for peat emissions where much higher absorption enhancement is observed. The peat burns give a very high value $(5.65 \pm 1.43)$ of $E_{\mathrm{AbsDen}}$ at $405 \mathrm{~nm}$ because smoldering emissions from peat are predominantly $\mathrm{BrC}$ with a negligible amount of $\mathrm{BC}$ content (Chakrabarty et al., 2016; Pokhrel et al., 2016; Stockwell et al., 2016). It is evident from Fig. 4 that $E_{\text {AbsDen }}$ can vary significantly, depending on burn conditions, even for the same fuel.

\subsection{Parameterization of absorption enhancement}

In order to gain a better understanding of what drives variation in $E_{\mathrm{AbsDen}}$, we examined correlations between absorption enhancement and other fire-relevant variables. It is notable that some regressions are done for a semi-log plot while others are linear or $\log -\log$. The type of regression was chosen based on objective criterion for simple regression. Namely that the residuals are equally scattered from the regression line and that the residuals are as close as possible 

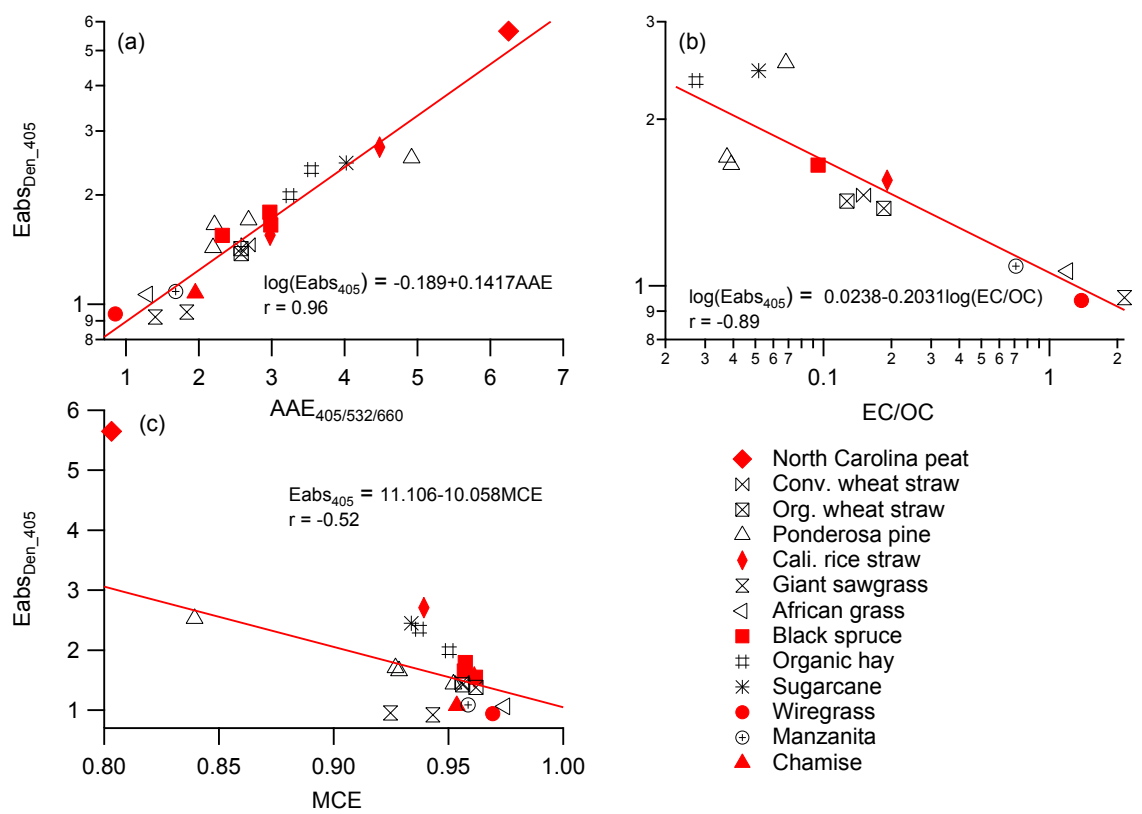

North Carolina peat

$\bowtie$ Conv. wheat straw

$\bowtie$ Org. wheat straw

$\triangle$ Ponderosa pine

- Cali. rice straw

\& Giant sawgrass

$\triangleleft$ African grass

- Black spruce

\# Organic hay

* Sugarcane

- Wiregrass

$\oplus$ Manzanita

- Chamise

Figure 5. $405 \mathrm{~nm}$ absorption enhancement parameterized with (a) AAE, (b) EC / OC, and (c) MCE. The symbols are sorted by fuel type and listed in the legend. Red lines are least-square fits of the data with the equation and correlation coefficient $(r)$ reported for each case. Given the near absence of BC, peat burns are considered as outliers and not included in model fit.

to a normal distribution. The model (either $\log Y$ vs. $\log X$, $\log Y$ vs. $X$, or $Y$ vs. $\log X$ ) which satisfied these criterion for simple linear regression was chosen. Fuel type alone is insufficient because $E_{\text {AbsDen }}$ varies dramatically during different burns of a single fuel. Figure 5 shows $E_{\text {AbsDen }}$ at $405 \mathrm{~nm}$ vs. the absorption Ångström exponent, elemental to organic carbon ratio (EC/OC), and MCE (Eq. 2). AAE values in Fig. 5 were calculated from a best fit to the logarithm of absorption coefficient vs. wavelength at three wavelengths (660, 532, $405 \mathrm{~nm})$, as detailed in Pokhrel et al. (2016). A strong positive correlation $(r=0.96)$ between absorption enhancement at $405 \mathrm{~nm}$ and AAE is observed for all fuels. The linear relationship between logarithm of $E_{\mathrm{AbsDen}}$ and $\mathrm{AAE}$ suggests that $\mathrm{BrC}$ absorption can be parameterized within the AAE framework. While the exact nature of the trend is notable, the trend itself is expected because the AAE of pure BC is typically near 1 (Kirchstetter and Thatcher, 2012; Wiegand et al., 2014) and anything larger than that strongly suggests the presence of absorbing coatings.

Figure 5a shows that for AAE less than $2, E_{\mathrm{AbsDen}}$ at $405 \mathrm{~nm}$ remains close to 1 , indicating little influence from $\mathrm{BrC}$ or coatings when emissions have a low AAE. Also for AAE less than 2, $E_{\mathrm{Abs} \text { Den }}$ at $660 \mathrm{~nm}$ (Fig. 6a) are similar to $E_{\mathrm{AbsDen}}$ at $405 \mathrm{~nm}$, again indicating little presence of $\mathrm{BrC}$, which is expected to absorb mainly at shorter wavelengths. Although $E_{\mathrm{AbsDen}}$ at $405 \mathrm{~nm}$ shows strong correlation with $\mathrm{AAE}, E_{\mathrm{AbsDen}}$ at $660 \mathrm{~nm}$ does not show good correlation, with a Pearson's correlation coefficient for logarithm of $E_{\mathrm{AbsDen}} \mathrm{vs}$. AAE of 0.96 at $405 \mathrm{~nm}$ but only 0.32 at
$660 \mathrm{~nm}$. This result strongly suggests that either $\mathrm{BrC}$ is not present at $660 \mathrm{~nm}$ or, if there is $\mathrm{BrC}$ at $660 \mathrm{~nm}$, it is not strongly correlated to AAE. This means that, if $E_{\mathrm{AbsDen}}$ $660 \mathrm{~nm}$ is purely from lensing, the effect of non-absorbing coatings on absorption cannot be easily parameterized with AAE.

Figures $4 \mathrm{~b}$ and $5 \mathrm{~b}$ show that $E_{\mathrm{AbsDen}}$ at both 405 and $660 \mathrm{~nm}$ decrease linearly ( $r=-0.89$ and -0.78 respectively) with the logarithm of the EC / OC ratio. When aerosol composition has more EC than OC, $E_{\mathrm{AbsDen}}$ at 405 and $660 \mathrm{~nm}$ both approach 1 as the effects of lensing and $\mathrm{BrC}$ become minimal. The slope of the 660 and $405 \mathrm{~nm} E_{\text {absDen }}$ vs. EC / OC fits are very different and as the fraction of OC increases, $E_{\mathrm{AbsDen}}$ at $405 \mathrm{~nm}$ grows much more quickly than $E_{\text {AbsDen }}$ at $660 \mathrm{~nm}$. Saleh et al. (2014) estimate that the average BC core and particle size during FLAME-4 was 100 and $200 \mathrm{~nm}$ respectively. In these size ranges, core-shell Mie theory predicts that the lensing effect will be similar at 660 and $405 \mathrm{~nm}$ (McMeeking et al., 2014). Given this, the much larger $E_{\text {absDen }}$ at $405 \mathrm{~nm}$ indicates absorption from BrC. A key observation is that $E_{\mathrm{AbsDen}}$ at $405 \mathrm{~nm}$ can be parameterized with EC / OC without the need to explicitly define fuel type. There is relatively poor correlation between $E_{\text {AbsDen }}$ at either 405 or $660 \mathrm{~nm}$ with MCE. There are fewer data points for EC / OC parameterizations because not all burns measured with the optical suite had corresponding EC / OC measurements. Accordingly, the linear fit of $E_{\mathrm{AbsDen}} \mathrm{vs.} \mathrm{MCE}$ at $405 \mathrm{~nm}$ does not include peat and one ponderosa pine burn (with MCE 0.83) because there was no EC / OC data for 

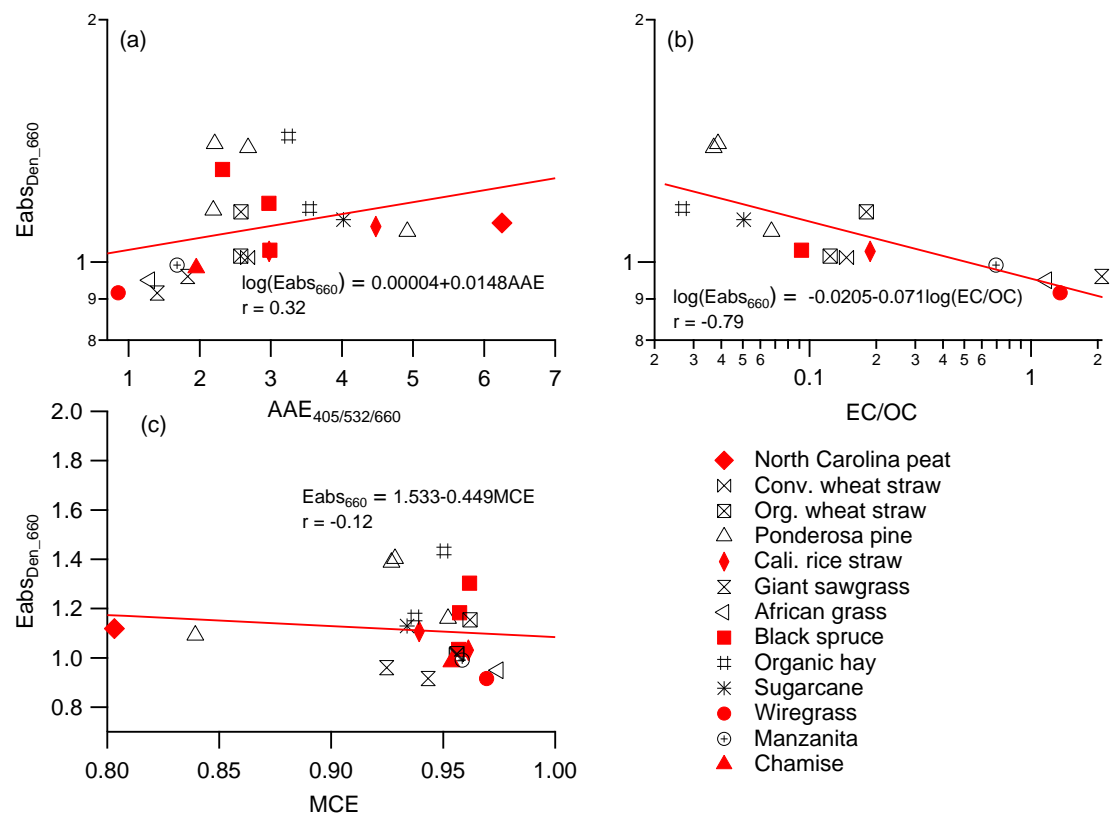

Figure 6. Same as Fig. 5 but for $660 \mathrm{~nm}$.

these burns and they represented significantly lower MCE than all other burns. For similar MCE values, $E_{\mathrm{AbsDen}}$ at $405 \mathrm{~nm}$ varies by a factor of 3 in some burns. A potential reason for the poor fit with MCE is the difficulty of MCE to predict aerosol properties such as $\mathrm{BC} / \mathrm{OA}$ or $\mathrm{EC} / \mathrm{OC}$ (Grieshop et al., 2009; Pokhrel et al., 2016) on which absorptivity of organic aerosol has a strong dependence (Saleh et al., 2014).

\subsection{Contribution to total absorption from brown carbon and lensing}

The dataset collected during this study allows us to estimate the contribution due to $\mathrm{BC}, \mathrm{BrC}$, and lensing in several different, commonly implemented, ways as discussed in the introduction. Here we describe the specific approaches used and evaluate the difference in the results generated by these approaches. A conceptual representation of these approaches is shown in Fig. 7.

\subsubsection{Approach 1: assume the thermal denuder removes all organic carbon and assume $\boldsymbol{E}_{\mathrm{Abs}}$ from lensing is constant at all wavelengths}

In this approach $E_{\mathrm{AbsDen}}$ at $660 \mathrm{~nm}$ is assumed as an enhancement due to lensing. We assume the absorption enhancement from lensing is identical at 405 and $660 \mathrm{~nm}$ (Guo et al., 2014; Nakayama et al., 2014; Cappa et al., 2012). We assume the absorption of the denuded channel at $405 \mathrm{~nm}$ is due entirely to BC. The remaining $E_{\mathrm{AbsDen}}$ after lensing is subtracted is assumed to be caused by $\mathrm{BrC}$. The following equations summarize these assumptions and describe how we derive the absorption from $\mathrm{BrC}$ at $405 \mathrm{~nm}$.

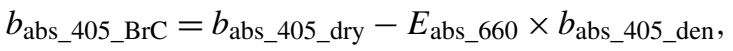

where $b_{\text {abs_405_BrC }}$ is absorption due to $\mathrm{BrC}$ at $405 \mathrm{~nm}$, $b_{\text {abs_405_dry }}$ is non-denuded dry absorption measured at $405 \mathrm{~nm}, b_{\text {abs_405_den }}$ is denuded absorption measured at $405 \mathrm{~nm}$, and $E_{\text {abs_660 }}$ is absorption enhancement at $660 \mathrm{~nm}$. Due to incomplete removal of low-volatile organics, estimated fraction of absorption due to $\mathrm{BrC}$ using approach 1 is most likely underestimated. The logic is that Eq. (3) can be simplified as

$$
\begin{aligned}
& b_{\text {abs_405_BrC }}=b_{\text {abs_4405_dry }}-E_{\text {abs_660 }} \times b_{\text {abs_405_den }} \\
& b_{\text {abs_405_BrC }}=b_{\text {abs_405_dry }}-\frac{b_{\text {abs_660_dry }}}{b_{\text {abs_660_den }}} \times b_{\text {abs_405_den }} .
\end{aligned}
$$

The denuded absorption at both 660 and $405 \mathrm{~nm}$ will be overestimated due to incomplete removal of organics, but the problem is expected to be worse at $405 \mathrm{~nm}$ because both $\mathrm{BrC}$ and lensing increase the $405 \mathrm{~nm}$ denuded absorption while lensing is the dominant effect for the 660 denuded absorption. Given this, the ratio $\frac{b_{\text {abs_40__den }}}{b_{\text {abs_60_den }}}$ is expected to be larger than 1 and hence $\mathrm{BrC}$ absorption will be underestimated because neither of the dry absorptions $(405,660 \mathrm{~nm})$ will be affected. To extend our results to $532 \mathrm{~nm}$, where dry, but not denuded, absorption was measured by the PAS, we calculated the absorption due to $\mathrm{BrC}$ as follows: 


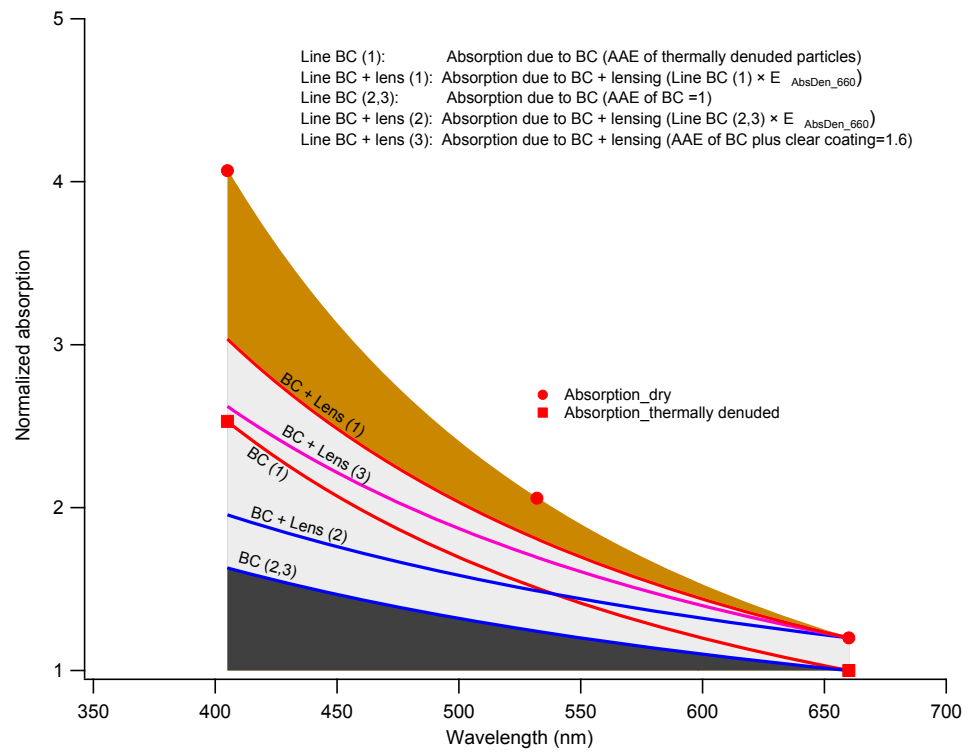

Figure 7. Conceptual representation of the three different approaches used to estimate the fraction of total absorption contributed by BC, $\mathrm{BrC}$, and lensing. Numbers in parentheses correspond to the approach represented by that line. The $y$ axis is normalized so that the denuded absorption of the $660 \mathrm{~nm}$ channel is unity.

$$
\begin{aligned}
b_{\text {abs_532_Brc }} & =b_{\text {abs_532_dry }}-E_{\text {abs_660 }} \times b_{\text {abs_405_den }} \\
& \times\left(\frac{405}{532}\right)^{\mathrm{AAE}_{\text {den }}},
\end{aligned}
$$

where $b_{\text {abs_532_Brc }}$ is absorption due to $\mathrm{BrC}$ at $532 \mathrm{~nm}$,

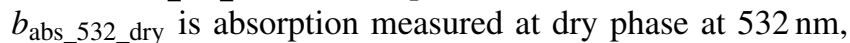
$E_{\text {abs_660 }}$ is absorption enhancement at $660 \mathrm{~nm}$, and $\mathrm{AAE}_{\mathrm{den}}$ is the absorption Angström exponent calculated between the 660 and $405 \mathrm{~nm}$ denuded channels. The BrC absorption estimated by Eqs. (3) and (4) can be visualized by subtracting dry absorption and the line labeled "BC + Lens (1)" in Fig. 7.

\subsubsection{Approach 2: assume $660 \mathrm{~nm}$ denuded absorption represents $\mathrm{BC}$ absorption, assume the $\mathrm{AAE}$ of $\mathrm{BC}$ is 1 , and assume $E_{\mathrm{Abs}}$ from lensing is constant at all wavelengths}

In this approach we assume the absorption measured in the denuded $660 \mathrm{~nm}$ channel is due entirely to $\mathrm{BC}$. We estimate absorption due to $\mathrm{BC}$ at wavelengths less than $660 \mathrm{~nm}$ using an AAE of 1 for BC. This approach may be more accurate than approach 1 if the thermal denuder does not effectively remove all of the $\mathrm{BrC}$ absorption at $405 \mathrm{~nm}$. This approach will be incorrect if the $\mathrm{AAE}$ of $\mathrm{BC}$ is different than 1 , if there is $\mathrm{BrC}$ at $660 \mathrm{~nm}$ that is not removed by the denuder or if the denuder generates $\mathrm{BC}$ at $660 \mathrm{~nm}$. $E_{\mathrm{AbsDen}}$ at $660 \mathrm{~nm}$ is considered to be due to lensing of the $\mathrm{BC}$ core and the same lensing effect is applied on all wavelengths. Absorption due to $\mathrm{BC}$ at any wavelength is estimated by using Eq. (5) (line "BC (2,3)" in Fig. 7), $b_{\text {mabs_} \_\lambda_{1} \_\mathrm{BC}}=b_{\mathrm{abs} \_660 \_ \text {den }} \times\left(\frac{660}{\lambda_{1}}\right)^{1}$,

and absorption due to $\mathrm{BrC}$ is estimated by the following:

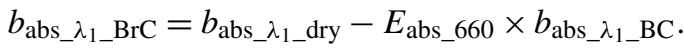

Substituting the value of $b_{\mathrm{abs} \_} \lambda_{1} \_\mathrm{BC}$ from Eq. (5) generates an alternate expression for absorption due to $\mathrm{BrC}$ :

$b_{\text {abs_} \_\lambda \_ \text {BrC }}=b_{\text {abs_ } \lambda_{1} \_ \text {dry }}-E_{\text {abs_660 }} \times b_{\text {abs_660_den }} \times\left(\frac{660}{\lambda_{1}}\right)^{1}$,

where $\lambda_{1}$ is the desired wavelength, which in this study is 405 and $532 \mathrm{~nm}$. Absorption from lensing is calculated as the difference between total absorption and the sum of the contributions from $\mathrm{BC}$ and $\mathrm{BrC}$ to absorption. BrC absorption estimation using Eq. (7) can be visualized by subtracting line "BC + Lens (2)" from the dry absorption in Fig. 7.

\section{Alternate description of approach 2}

A widely used approach is to assume that absorption at $660 \mathrm{~nm}$ or higher wavelengths is equivalent to $\mathrm{BC}$ absorption plus lensing from the clear coating because there is no absorption contribution from $\mathrm{BrC}$. It is also assumed that coated $\mathrm{BC}$ particles have an AAE of 1, similar to uncoated BC. Absorption due to $\mathrm{BC}$ at lower wavelengths is estimated as

$b_{\text {abs_ } \lambda_{1 \_} \mathrm{BC}}=b_{\text {abs_660_dry }} \times\left(\frac{660}{\lambda_{1}}\right)^{1}$

and absorption due to $\mathrm{BrC}$ is estimated as 
$b_{\text {abs_ } \lambda_{1} \_ \text {BrC }}=b_{\text {abs_ } \lambda \lambda_{1} \text { dry }}-b_{\text {abs_660_dry }} \times\left(\frac{660}{\lambda_{1}}\right)^{1}$.

Interestingly, because $b_{\text {abs_660_dry }}=E_{\text {abs_660 }} b_{\text {abs_660_den, }}$, Eqs. (9) and (7) are equivalent. Therefore, this approach gives the same absorption due to $\mathrm{BrC}$ as what was described for approach 2 and there is no need to call this a separate approach. It is described here because it is widely implemented by groups without a thermal denuder and to demonstrate that several different assumptions lead to the same numerical result for BrC absorption. Importantly, Eqs. (8) and (9) do not allow for assessment of the impact of lensing while Eqs. (5) and (6) do. A final note is that one also arrives at Eq. (9) if it is assumed that lensing has a negligible impact on BC properties and all absorption at $660 \mathrm{~nm}$ is from BC. However, this is a rather unrealistic approach given that lensing has clearly been shown to impact absorption at $660 \mathrm{~nm}$.

\subsubsection{Approach 3: assume $660 \mathrm{~nm}$ denuded is BC absorption, assume $660 \mathrm{~nm}$ dry is $\mathrm{BC}$ plus lensing, assume clear-coated $\mathrm{BC}$ has $\mathrm{AAE}$ of 1.6}

AAE for non-denuded BC has been commonly assigned as 1.0 in many past studies, including some recent studies (Kirchstetter and Thatcher, 2012; Wiegand et al., 2014). However, it has been shown theoretically that with a nonabsorbing coating, AAE of BC can be as large as 1.6 (Gyawali et al., 2009; Lack and Cappa, 2010). Here we use AAE of 1 for uncoated BC and AAE of 1.6 for coated BC. This approach estimates an approximate maximum increase in lensing with decreasing wavelength rather than assuming it is constant with wavelength as in the other approaches. It is an important reference point because while BrC may bleach (Wang et al., 2016; Forrister et al., 2015; Lee et al., 2014), absorption enhancement from lensing will remain unless coatings evaporate. Absorption due to $\mathrm{BC}$, lensing, and $\mathrm{BrC}$ is calculated as follows:

Absorption due to $\mathrm{BC}$ is estimated as

$b_{\text {abs_ } \lambda_{1} \_ \text {BC }}=b_{\text {abs_660_den }} \times\left(\frac{660}{\lambda_{1}}\right)^{1}$

and absorption due to $\mathrm{BrC}$ is estimated by

$b_{\text {abs_ } \lambda_{1} \_\mathrm{BrC}}=b_{\mathrm{abs} \_\lambda_{1} \_\mathrm{dry}}-b_{\text {abs_660_dry }} \times\left(\frac{660}{\lambda_{1}}\right)^{1.6}$,

where $b_{\text {abs_ } \lambda_{1} \_\mathrm{BC}}$ is absorption due to $\mathrm{BC}$ at wavelength $\lambda_{1}, b_{\text {abs_660_den }}$ is denuded absorption measured at $660 \mathrm{~nm}$, $b_{\text {abs_ } \lambda_{1} \_\mathrm{BrC}}$ is absorption due to $\mathrm{BrC}$ at $\lambda_{1}, b_{\text {abs_ } \lambda_{1} \text { dry }}$ is non-denuded absorption measured at $\lambda_{1}, b_{\text {abs_660_dry }}$ is nondenuded absorption measured at $660 \mathrm{~nm}$, and $\lambda_{1}$ is the desired wavelength (405 and $532 \mathrm{~nm}$ in this study). BrC estimated by Eq. (11) can be visualized as the difference between the dry absorption and line "BC + Lens (3)" in Fig. 7.
Absorption contribution due to lensing is estimated by subtracting absorption due to $\mathrm{BC}$ and $\mathrm{BrC}$ from the total absorption.

Based on these approaches, the contribution of $\mathrm{BC}, \mathrm{BrC}$, and lensing to total absorption by biomass burning aerosol under different burn conditions is estimated. Table 1 summarizes the results at $405 \mathrm{~nm}$. BrC at $405 \mathrm{~nm}$ is estimated to contribute 0 to $92 \%$ of total biomass burning aerosol absorption depending upon the burn and the approach used. From multiple burns of the same fuel (pine, California rice straw, black spruce, organic hay, organic wheat) it is evident that the $\mathrm{BrC}$ contribution to absorption changes significantly for a single fuel demonstrating the importance of burn conditions. Between the three different approaches, the lower bound for the contribution of $\mathrm{BrC}$ estimation is consistently approach 1 and the upper bound is consistently approach 2, with approach 3 being in the middle. We hypothesize that the reason for approach 1 consistently resulting in the lowest fraction of absorption from $\mathrm{BrC}$ is incomplete removal of organics by the thermal denuder, an idea that is supported by the observation that the AAE of the denuded aerosol channels (405 and $660 \mathrm{~nm}$ ) was often significantly larger than one, which is often observed for uncoated $\mathrm{BC}$ (average $\mathrm{AAE}_{\mathrm{den}}=1.9$ ). It is thought that the resonance time of aerosol in the thermal denuder may have been insufficient to remove the significant coatings present in some burns or that the temperature $\left(250^{\circ} \mathrm{C}\right)$ could have been too low to remove extremely lowvolatility organic compounds that have been suggested to be important contributors to BrC (Saleh et al., 2014). While this suggests that the $\mathrm{BrC}$ contributions derived from approach 2 may be closer to reality, approach 1 provides a useful lower bound to $\mathrm{BrC}$ absorption and even this lower bound is often a significant fraction of total absorption. The difference in BrC contribution predicted by approach 1 and 2 varies from burn to burn with a maximum ratio of 4.3 and a mean ratio of 2.1, demonstrating the significant variation between methodologies and the potential difficulties of assessing $\mathrm{BrC}$ via thermal denuding. Similar to the $405 \mathrm{~nm}$ results, the $\mathrm{BrC}$ contribution at $532 \mathrm{~nm}$ is important to overall absorption and shows large variations, ranging from 0 to $58 \%$ as shown in Table S2. The percentage of absorption due to $\mathrm{BrC}$ at $532 \mathrm{~nm}$ also has a strong dependency on fuel type and the methodology used, similar to the $405 \mathrm{~nm}$ results.

The maximum ratio of the $\mathrm{BrC}$ contributions found in approach 1 and 2 is 2.5 at $532 \mathrm{~nm}$, lower than the maximum difference at $405 \mathrm{~nm}$. However, the mean ratio is 2.1 , which is identical to the $405 \mathrm{~nm}$ results. We find that coatings can contribute up to roughly $30 \%$ of the absorption, but generally the contribution due to coating is low relative to $\mathrm{BC}$ and BrC. However, it should be noted that incomplete removal of organics by the thermal denuder would result in an underestimate of absorption enhancement from clear coatings (lensing) and an overestimate of the relative importance of BC in all three approaches. Approach 3 consistently yields the highest contribution from coatings, suggesting that an 
Table 1. Percentage of absorption due to $\mathrm{BC}$, lensing (clear coating), and $\mathrm{BrC}$ from biomass burning aerosol emissions at $405 \mathrm{~nm}$ estimated from three different approaches. The ID is the fire ID assigned during FLAME-4 for particular burns. The ratio in the rightmost column is the ratio in $\mathrm{BrC}$ absorption estimated by approach 2 vs. approach 1. Results where the $\mathrm{BrC}$ contribution was found to be zero by approach 1 are not assigned a ratio. NA indicates not available.

\begin{tabular}{|c|c|c|c|c|c|c|c|c|c|c|c|}
\hline \multirow[t]{2}{*}{ ID } & \multirow[t]{2}{*}{ Materials } & \multicolumn{3}{|c|}{ Approach 1} & \multicolumn{3}{|c|}{ Approach 2} & \multicolumn{3}{|c|}{ Approach 3} & \multirow[b]{2}{*}{ Ratio } \\
\hline & & $\mathrm{BC}$ & Coat & $\mathrm{BrC}$ & $\mathrm{BC}$ & Coat & $\mathrm{BrC}$ & $\mathrm{BC}$ & Coat & $\mathrm{BrC}$ & \\
\hline 129 & Pine & 38 & 3 & 58 & 14 & 1 & 85 & 14 & 6 & 80 & 1.5 \\
\hline 142 & Pine & 68 & 11 & 21 & 48 & 10 & 42 & 48 & 30 & 22 & 2.0 \\
\hline 144 & Pine & 55 & 21 & 23 & 30 & 14 & 57 & 30 & 29 & 42 & 2.5 \\
\hline 130 & California rice straw & 64 & 2 & 34 & 37 & 2 & 62 & 37 & 15 & 49 & 1.8 \\
\hline 143 & California rice straw & 35 & 4 & 61 & 16 & 2 & 82 & 16 & 8 & 76 & 1.3 \\
\hline 131 & Black Spruce & 59 & 2 & 39 & 37 & 2 & 60 & 37 & 16 & 46 & 1.5 \\
\hline 134 & Black Spruce & 55 & 10 & 35 & 35 & 6 & 59 & 35 & 20 & 45 & 1.7 \\
\hline 138 & Organic Hay & NA & NA & NA & 29 & 11 & 60 & 29 & 24 & 47 & NA \\
\hline 146 & Organic Hay & 41 & 7 & 53 & 28 & 0 & 72 & 29 & 9 & 62 & 1.4 \\
\hline 132 & Organic Wheat & 70 & 1 & 29 & 48 & 1 & 52 & 48 & 17 & 35 & 1.8 \\
\hline 149 & Organic Wheat & 73 & 11 & 16 & 40 & 6 & 54 & 40 & 21 & 38 & 3.4 \\
\hline 139 & Giant saw grass & 100 & 0 & 0 & 86 & 0 & 14 & 86 & 14 & 0 & - \\
\hline 148 & Giant saw grass & NA & NA & NA & NA & NA & NA & 66 & 22 & 12 & NA \\
\hline 133 & Conventional Wheat & 68 & 1 & 32 & 45 & 1 & 54 & 45 & 17 & 38 & 1.7 \\
\hline 135 & Chamise & 93 & 0 & 7 & 64 & 0 & 37 & 64 & 21 & 15 & 5.3 \\
\hline 136 & Manzanita & 92 & 0 & 8 & 73 & 0 & 28 & 73 & 24 & 3 & 3.5 \\
\hline 141 & Wire grass & 100 & 0 & 0 & 100 & 0 & 0 & 100 & 0 & 0 & - \\
\hline 147 & Sugar cane & 40 & 5 & 55 & 21 & 2 & 77 & 21 & 10 & 69 & 1.4 \\
\hline 150 & $\mathrm{NC}$ peat & 16 & 2 & 82 & 8 & 0 & 92 & 8 & 3 & 89 & 1.1 \\
\hline
\end{tabular}

Ångström exponent of 1.6 for BC with clear coatings is indeed at the high end of possible AAE values.

Our estimation of $\mathrm{BrC}$ contribution to total biomass burning aerosol absorption shows large variations, but it is also clear that, independent of methodology, the contribution of $\mathrm{BrC}$ to total absorption is large and often of similar or greater magnitude than the contribution from BC. Most ambient studies show relatively low $(<20 \%) \mathrm{BrC}$ contribution to absorption at $405 \mathrm{~nm}$ (Yuan et al., 2016; Nakayama et al., 2014; Cappa et al., 2012), but these studies were not focused on biomass burning emissions and had significantly less biomass burning influence. Lack et al. (2012a) estimated that $\mathrm{BrC}$ contributed $27 \pm 15 \%$ of absorption at $405 \mathrm{~nm}$ during a wild fire in Boulder, Colorado, based on thermal denuder measurements. Additional studies focused on biomass burning reported ranges of values for the contribution to absorption from $\mathrm{BrC}$ (McMeeking et al., 2014; Flowers et al., 2009) and these ranges are similar to ours. Flowers et al. (2009) showed BrC can contribute $27-51 \%$ of absorption at $405 \mathrm{~nm}$ using literature mass absorption cross section (MAC) values to estimate the absorption due to $\mathrm{BC}$ and calculating absorption due to $\mathrm{BrC}$ by comparing measured absorption with estimated absorption based on MAC and BC mass. McMeeking et al. (2014) found, based on fresh emissions from a wide range of biomass fuels, that non-refractory particulate matter can contribute $20-80 \%$ of the light absorption at wavelengths $\leq 532 \mathrm{~nm}$, a result similar to the range of contributions to absorption from $\mathrm{BrC}(0-92 \%)$ found in this study.

\subsection{Parameterization of brown carbon absorption}

Given the large variation in the contribution of $\mathrm{BrC}$ to total absorption for different fuels and for repeated burns of the same fuel, it is clear that some type of framework for estimating the significance of $\mathrm{BrC}$ absorption is needed. Saleh et al. (2014) developed a methodology to estimate the imaginary part of the refractive index of $\mathrm{BrC}$ based on the ratio of black carbon to organic aerosol mass. This approach requires detailed particle size measurements that were not available in the current study. Instead, we directly parameterize the contribution of $\mathrm{BrC}$ to biomass burning aerosol absorption with MCE, EC / OC, and AAE. Figure 8 shows the percentage of absorption due to $\mathrm{BrC}$ at 405 and $532 \mathrm{~nm}$ estimated with approaches 1-3 vs. EC / OC and AAE. The general pattern is that the fraction of absorption due to $\mathrm{BrC}$ is highest when the aerosol composition is dominated by OC. On the other hand, aerosol composition dominated by EC shows a lower contribution to total absorption from $\mathrm{BrC}$ at both wavelengths. Generally, the trend of the fraction of $\mathrm{BrC}$ absorption vs. EC / OC is similar for different approaches, but the slopes of the lines change significantly based on the approach. The percentage of absorption due to $\mathrm{BrC}$ at 405 and $532 \mathrm{~nm}$ shows a reasonably good correlation with EC / OC, as demonstrated by the correlation coefficients between 0.7 

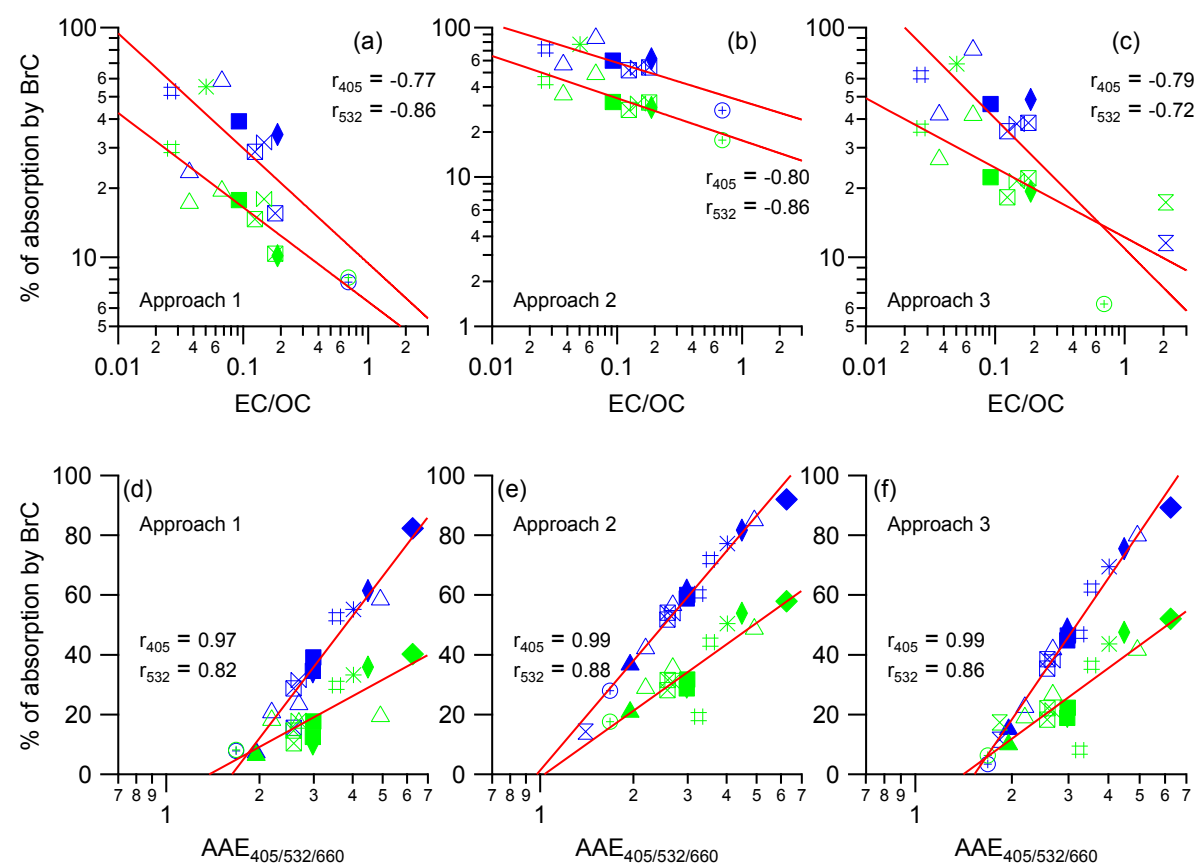

Figure 8. Percentage of absorption due to BrC vs. EC / OC - (a) for approach 1, (b) for approach 2, and (c) for approach 3. Blue symbols are for $405 \mathrm{~nm}$ and green symbols are for $532 \mathrm{~nm}$. Panels (d)-(f) are the same as the top row of data except vs. AAE.

and 0.9 shown in Fig. 8a-c. We also parameterize the $\mathrm{BrC}$ percentage with AAE and find that AAE shows very good correlation with the percentage of absorption due to $\mathrm{BrC}$ yielding correlation coefficients between 0.8 and 0.99 . Figure $8 \mathrm{~d}-\mathrm{f}$ shows that for an AAE less than 2, contributions from $\mathrm{BrC}$ are less than about $20 \%$ and decrease with decreasing AAE regardless of the approach used to estimate these values. Also, there is a higher contribution to absorption from $\mathrm{BrC}$ at $405 \mathrm{~nm}$ vs. $532 \mathrm{~nm}$ at AAEs above roughly 2.5. On the other hand, MCE (Fig. S1 in the Supplement) does not have an easily fitted relationship with the percentage of absorption from $\mathrm{BrC}$ at either wavelength. For an MCE of 0.92 or greater, the percentage of absorption by $\mathrm{BrC}$ varies by a factor of 3 to 4 for very similar MCE values. The coefficients for each fitted line in Fig. 8 are reported in Table S3.

\section{Conclusions}

In this study 12 different fuels, representing globally significant sources of biomass burning aerosol emissions, were burned in 22 individual burns. Absorption enhancements determined based on thermally denuding the aerosol $\left(E_{\mathrm{AbsDen}}\right)$ at $405 \mathrm{~nm}$ are large when the biomass plume is dominated by organic carbon emissions. We observed large variations in $E_{\mathrm{AbsDen}}$ at $405 \mathrm{~nm}$ with a maximum value of $5.6 \pm 1.0$. $E_{\mathrm{AbsDen}}$ at $660 \mathrm{~nm}$ is generally low (with the maximum value of $1.433 \pm 0.166)$ suggesting that lensing is a less important contributor to biomass burning aerosol absorption than $\mathrm{BrC}(\mathrm{BrC})$ at the blue end of the visible spectrum.
From multiple burns of the same fuel, it is observed that $E_{\mathrm{AbsDen}}$ has a strong dependency on burn condition and that knowledge of fuel type is insufficient to predict $\mathrm{BrC}$. $E_{\text {AbsDen }}$ shows good correlation with both AAE $(r=0.96)$ and EC / OC $(r=-0.89)$ but has limited correlation with MCE $(r=-0.39)$. We suspect that the $E_{\text {AbsDen }}$ values at 660 and $405 \mathrm{~nm}$ are lower bounds because the thermal denuder may not have removed all organic material. To address this concern, we estimated the fraction of total aerosol absorption due to $\mathrm{BC}, \mathrm{BrC}$, and lensing and found that the fraction of absorption from $\mathrm{BrC}$ could vary by up to a factor of 4.3 depending on the approach utilized. The average ratio of the fraction of absorption from $\mathrm{BrC}$ found via a method assuming the $\mathrm{AAE}$ of $\mathrm{BC}$ was $1 \mathrm{vs}$. the thermal denuder method is 2.1 at $405 \mathrm{~nm}$. We found that $\mathrm{BrC}$ can contribute up to $92 \%$ of total aerosol absorption at $405 \mathrm{~nm}$ and up to $58 \%$ of total absorption at $532 \mathrm{~nm}$ while lensing can contribute a maximum of $30 \%$ but typically contributes much less than this, though the impact of lensing could be underestimated if the denuder did not remove all organic material. The fraction of absorption from $\mathrm{BrC}$ shows reasonably good correlation with AAE and EC / OC at both 405 and $532 \mathrm{~nm}$ (independent of the approach used) but has a poor correlation with MCE. The fractional absorption due to $\mathrm{BrC}$ at 405 and $532 \mathrm{~nm}$ increases as the EC / OC ratio decreases. This result is distinct but not inconsistent with Saleh et al. (2014) who found that the imaginary index of refraction increases with increasing $\mathrm{BC} / \mathrm{OA}$ ratio. These two results can be understood with the idea that $\mathrm{BrC}$ grows darker as emissions have a higher frac- 
tion of black carbon relative to non-refractory organic mass, but the fraction of total absorption caused by BrC increases as the amount of organic mass increases and the black carbon to organic carbon mass ratio decreases.

Data availability. All the data presented in this paper can be accessed via email request to Shane Murphy (shane.murphy@uwyo.edu).

\section{The Supplement related to this article is available online at doi:10.5194/acp-17-5063-2017-supplement.}

Competing interests. The authors declare that they have no conflict of interest.

Acknowledgements. This material is based upon work supported by the National Science Foundation under grant no. 1241479. Chelsea E. Stockwell and Robert J. Yokelson were supported primarily by NSF grant ATM-0936321. Thilina Jayarathne and Elizabeth A. Stone were supported by the University of Iowa. We thank Ted Christian, Dorothy L. Fibiger, and Shunsuke Nakao for assistance with filter sample collection and sample preparation. We appreciate the contribution of Eric Miller, David Weise, Greg Askins, Guenter Engling, Savitri Garivait, Christian L'Orange, Benjamin Legendre, Brian Jenkins, Emily Lincoln, Navashni Govender, Chris Geron, and Kary Peterson for harvesting the fuels for this study. Collection of Indonesian peat by Kevin Ryan and Mark Cochrane was supported by NASA Earth Science Division Award NX13AP46. We also thank Daniel Murphy for valuable suggestions during data collection and manuscript preparation.

Edited by: $\mathrm{H}$. $\mathrm{Su}$

Reviewed by: three anonymous referees

\section{References}

Alexander, D. T. L., Crozier, P., and Anderson, J. R.: Brown carbon spheres in East Asian outflow and their optical properties, Science, 321, 833-836, doi:10.1126/science.1155296, 2008.

Anderson, S. M. and Mauersberg, K.: Laser measurements of ozone absorption cross section in the Chappuis band, Geophys. Res. Lett., 19, 933-936, 1992.

Axson, J. L., Washenfelder, R. A., Kahan, T. F., Young, C. J., Vaida, V., and Brown, S. S.: Absolute ozone absorption cross section in the Huggins Chappuis minimum (350-470 nm) at 296 K, Atmos. Chem. Phys., 11, 11581-11590, doi:10.5194/acp11-11581-2011, 2011.

Bahadur, R., Praveen, P. S., Xu, Y., and Ramanathan, V.: Solar absorption by elemental and brown carbon determined from spectral observations, P. Natl. Acad. Sci. USA, 109, 17366-17371, doi:10.1073/pnas.1205910109, 2012.

Barnard, J. C., Volkamer, R., and Kassianov, E. I.: Estimation of the mass absorption cross section of the organic carbon component of aerosols in the Mexico City Metropolitan Area (MCMA), Atmos. Chem. Phys., 8, 6665-6679, doi:10.5194/acp-8-6665-2008, 2008.

Bond, T. C.: Spectral dependence of visible light absorption by carbonaceous particles emitted from coal combustion, Geophys. Res. Lett., 28, 4075-4078, doi:10.1029/2001GL013652, 2001.

Bond, T. C., Habib, G., and Bergstrom, R. W.: Limitations in the enhancement of visible light absorption due to mixing state, $\mathrm{J}$. Geophys. Res., 111, D20211, doi:10.1029/2006JD007315, 2006.

Bond, T. C., Doherty, S. J., Fahey, D. W., Forster, P. M., Berntsen, T., Deangelo, B. J., Flanner, M. G., Ghan, S., Kärcher, B., Koch, D., Kinne, S., Kondo, Y., Quinn, P. K., Sarofim, M. C., Schultz, M. G., Schulz, M., Venkataraman, C., Zhang, H., Zhang, S., Bellouin, N., Guttikunda, S. K., Hopke, P. K., Jacobson, M. Z., Kaiser, J. W., Klimont, Z., Lohmann, U., Schwarz, J. P., Shindell, D., Storelvmo, T., Warren, S. G., and Zender, C. S.: Bounding the role of black carbon in the climate system: A scientific assessment, J. Geophys. Res.-Atmos., 118, 5380-5552, doi:10.1002/jgrd.50171, 2013.

Cappa, C. D., Onasch, T. B., Massoli, P., Worsnop, D. R., Bates, T. S., Cross, E. S., Davidovits, P., Hakala, J., Hayden, K. L., Jobson, B. T., Kolesar, K. R., Lack, D. A., Lerner, B. M., Li, S.-M., Mellon, D., Nuaaman, I., Olfert, J. S., Petaja, T., Quinn, P. K., Song, C., Subramanian, R., Williams, E. J., and Zaveri, R. A.: Radiative Absorption Enhancements Due to the Mixing State of Atmospheric Black Carbon, Science, 337, 1078-1081, doi:10.1126/science.1223447, 2012.

Cazorla, A., Bahadur, R., Suski, K. J., Cahill, J. F., Chand, D., Schmid, B., Ramanathan, V., and Prather, K. A.: Relating aerosol absorption due to soot, organic carbon, and dust to emission sources determined from in-situ chemical measurements, Atmos. Chem. Phys., 13, 9337-9350, doi:10.5194/acp-13-9337-2013, 2013.

Chakrabarty, R. K., Gyawali, M., Yatavelli, R. L. N., Pandey, A., Watts, A. C., Knue, J., Chen, L.-W. A., Pattison, R. R., Tsibart, A., Samburova, V., and Moosmüller, H.: Brown carbon aerosols from burning of boreal peatlands: microphysical properties, emission factors, and implications for direct radiative forcing, Atmos. Chem. Phys., 16, 3033-3040, doi:10.5194/acp-163033-2016, 2016.

Chang, D. and Song, Y.: Estimates of biomass burning emissions in tropical Asia based on satellite-derived data, Atmos. Chem. Phys., 10, 2335-2351, doi:10.5194/acp-10-2335-2010, 2010.

Chen, Y. and Bond, T. C.: Light absorption by organic carbon from wood combustion, Atmos. Chem. Phys., 10, 1773-1787, doi:10.5194/acp-10-1773-2010, 2010.

Cheng, Y., He, K. B., Duan, F. K., Zheng, M., Ma, Y. L., and Tan, J. H.: Positive sampling artifact of carbonaceous aerosols and its influence on the thermal-optical split of OC/EC, Atmos. Chem. Phys., 9, 7243-7256, doi:10.5194/acp-9-7243-2009, 2009.

Clinton, N. E., Gong, P., and Scott, K.: Quantification of pollutants emitted from very large wildland fires in southern California, USA, Atmos. Environ., 40, 3686-3695, doi:10.1016/j.atmosenv.2006.02.016, 2006.

Favez, O., Alfaro, S. C., Sciare, J., Cachier, H., and Abdelwahab, M. M.: Ambient measurements of light-absorption by agricultural waste burning organic aerosols, J. Aerosol. Sci., 40, 613-620, 2009 . 
Feng, Y., Ramanathan, V., and Kotamarthi, V. R.: Brown carbon: A significant atmospheric absorber of solar radiation, Atmos. Chem. Phys., 13, 8607-8621, doi:10.5194/acp-13-8607-2013, 2013.

Fialho, P., Hansen, A. D. A., and Honrath, R. E.: Absorption coefficients by aerosols in remote areas: a new approach to decouple dust and black carbon absorption co-efficients using seven wavelength Aethalometer data, J. Aerosol Sci., 36, 267-282, doi:10.1016/j.jaerosci.2004.09.004, 2005.

Fierz, M., Vernooij, M. G. C., and Burtscher, H.: An improved lowflow thermodenuder, J. Aerosol Sci., 38, 1163-1168, 2007.

Flowers, B. A., Dubey, M. K., Mazzoleni, C., Stone, E. A., Schauer, J. J., Kim, S.-W., and Yoon, S. C.: Optical-chemicalmicrophysical relationships and closure studies for mixed carbonaceous aerosols observed at Jeju Island; 3-laser photoacoustic spectrometer, particle sizing, and filter analysis, Atmos. Chem. Phys., 10, 10387-10398, doi:10.5194/acp-10-10387-2010, 2010.

Forrister, H., Liu, J., Scheuer, E., Dibb, J., Ziemba, L., Thornhill, K. L., Anderson, B., Diskin, G., Perring, A. E., Schwarz, J. P., Campuzano-Jost, P., Day, D. A., Palm, B. B., Jimenez, J. L., Nenes, A., and Weber, R. J.: Evolution of brown carbon in wildfire plumes, Geophys. Res. Lett., 42, 4623-4630, doi:10.1002/2015GL063897, 2015.

Fuller, K. A., Malm, W. C., and Kreidenweis, S. M.: Effects of mixing on extinction by carbonaceous particles, J. Geophys. Res., 104, 15941-15954, doi:10.1029/1998JD100069, 1999.

Grieshop, A. P., Logue, J. M., Donahue, N. M., and Robinson, A. L.: Laboratory investigation of photochemical oxidation of organic aerosol from wood fires 1: Measurement and simulation of organic aerosol evolution, Atmos. Chem. Phys., 9, 1263-1277, doi:10.5194/acp-9-1263-2009, 2009.

Guo, X., Nakayama, T., Yamada, H., Inomata, S., Tonokura, K. and Matsumi, Y.: Measurement of the light absorbing properties of diesel exhaust particles using a three-wavelength photoacoustic spectrometer, Atmos. Environ., 94, 428-437, doi:10.1016/j.atmosenv.2014.05.042, 2014.

Gyawali, M., Arnott, W. P., Lewis, K., and Moosmüller, H.: In situ aerosol optics in Reno, NV, USA during and after the summer 2008 California wildfires and the influence of aerosol coatings, Atmos. Chem. Phys., 9, 8007-8015, doi:10.5194/acp-98007-2009, 2009.

Jacobson, M. Z.: Effects of biomass burning on climate, accounting for heat and moisture fluxes, black and brown carbon, and cloud absorption effects, J. Geophys. Res.-Atmos., 119, 89809002, doi:10.1002/2014JD021861, 2014.

Kirchstetter, T. W. and Thatcher, T. L.: Contribution of organic carbon to wood smoke particulate matter absorption of solar radiation, Atmos. Chem. Phys., 12, 6067-6072, doi:10.5194/acp-126067-2012, 2012.

Kirchstetter, T. W., Novakov, T., and Hobbs, P. V.: Evidence that the spectral dependence of light absorption by aerosols is affected by organic carbon, J. Geophys. Res., 109, D21208, doi:10.1029/2004JD004999, 2004.

Lack, D. A. and Cappa, C. D.: Impact of brown and clear carbon on light absorption enhancement, single scatter albedo and absorption wavelength dependence of black carbon, Atmos. Chem. Phys., 10, 4207-4220, doi:10.5194/acp-10-4207-2010, 2010.

Lack, D. A., Lovejoy, E. R., Baynard, T., Pettersson, A., and Ravishankara, A. R.: Aerosol Absorption Measurement us- ing Photoacoustic Spectroscopy: Sensitivity, Calibration, and Uncertainty Developments, Aerosol Sci. Tech., 40, 697-708, doi:10.1080/02786820600803917, 2006.

Lack, D. A., Langridge, J. M., Bahreini, R., Cappa, C. D., Middlebrook, A. M., and Schwarz, J. P.: Brown carbon and internal mixing in biomass burning particles, P. Natl. Acad. Sci. USA, 109, 14802-14807, doi:10.1073/pnas.1206575109, 2012a.

Lack, D. A., Richardson, M. S., Law, D., Langridge, J. M., Cappa, C. D., McLaughlin, R. J., and Murphy, D. M.: Aircraft Instrument for Comprehensive Characterization of Aerosol Optical Properties, Part 2: Black and Brown Carbon Absorption and Absorption Enhancement Measured with Photo Acoustic Spectroscopy, Aerosol Sci. Tech., 46, 555-568, doi:10.1080/02786826.2011.645955, 2012b.

Langridge, J. M., Richardson, M. S., Lack, D., Law, D. and Murphy, D. M.: Aircraft Instrument for Comprehensive Characterization of Aerosol Optical Properties, Part I: Wavelength-Dependent Optical Extinction and Its Relative Humidity Dependence Measured Using Cavity Ringdown Spectroscopy, Aerosol Sci. Tech., 45, 1305-1318, doi:10.1080/02786826.2011.592745, 2011.

Laskin, A., Laskin, J., and Nizkorodov, S. A.: Chemistry of Atmospheric Brown Carbon, Chem. Rev., 115, 4335-4382, doi:10.1021/cr5006167, 2015.

Lee, H. J., Aiona, P. K., Laskin, A., Laskin, J. and Nizkorodov, S. A.: Effect of solar radiation on the optical properties and molecular composition of laboratory proxies of atmospheric brown carbon, Environ. Sci. Technol., 48, 10217-10226, doi:10.1021/es502515r, 2014.

Lin, G., Penner, J. E., Flanner, M. G., Sillman, S., Xu, L., and Zhou, C.: Radiative forcing of organic aerosol in the atmosphere and on snow: Effects of SOA and brown carbon, J. Geophys. Res.Atmos., 119, 7453-7476, doi:10.1002/2013JD021186, 2014.

Lin, P., Liu, J., Shilling, J. E., Kathmann, S. M., Laskin, J. and Laskin, A.: Molecular characterization of brown carbon $(\mathrm{BrC})$ chromophores in secondary organic aerosol generated from photo-oxidation of toluene, Phys. Chem. Chem. Phys., 17, 23312-23325, doi:10.1039/C5CP02563J, 2015.

Liu, D., Taylor, J. W., Young, D. E., Flynn, M. J., Coe, H., and Allan, J. D.: The effect of complex black carbon microphysics on the determination of the optical properties of brown carbon, Geophys. Res. Lett., 42, 613-619, doi:10.1002/2014GL062443, 2015.

Liu, J., Scheuer, E., Dibb, J., Ziemba, L. D., Thornhill, K. L., Anderson, B. E., Wisthaler, A., Mikoviny, T., Devi, J. J., Bergin, M. and Weber, R. J.: Brown carbon in the continental troposphere, Geophys. Res. Lett., 41, 2191-2195, doi:10.1002/2013GL058976, 2014.

Liu, S., Aiken, A. C., Arata, C., Dubey, M. K., Stockwell, C. E., Yokelson, R. J., Stone, E. A., Jayarathne, T., Robinson, A. L., Demott, P. J., and Kreidenweis, S. M.: Aerosol single scattering albedo dependence on biomass combustion efficiency: Laboratory and field studies, Geophys. Res. Lett., 41, 742-748, doi:10.1002/2013GL058392, 2014.

Lu, Z., Streets, D. G., Winijkul, E., Yan, F., Chen, Y., Bond, T. C., Feng, Y., Dubey, M. K., Liu, S., Pinto, J. P., and Carmichael, G. R.: Light Absorption Properties and Radiative Effects of Primary Organic Aerosol Emissions, Environ. Sci. Technol., 49, 48684877, doi:10.1021/acs.est.5b00211, 2015. 
May, A. A., Levin, E. J. T., Hennigan, C. J., Riipinen, I., Lee, T., Collett, J. L., Jimenez, J. L., Kreidenweis, S. M., and Robinson, A. L.: Gas-particle partitioning of primary organic aerosol emissions: 3. Biomass burning, J. Geophys. Res.-Atmos., 118, 11327-11338, doi:10.1002/jgrd.50828, 2013.

McCarty, J. L., Justice, C. O., and Korontzi, S.: Agricultural burning in the Southeastern United States detected by MODIS, Remote Sens. Environ., 108, 151-162, doi:10.1016/j.rse.2006.03.020, 2007.

McMeeking, G. R., Fortner, E., Onasch, T. B., Taylor, J. W., Flynn, M., Coe, H., and Kreidenweis, S. M.: Impacts of nonrefractory material on light absorption by aerosols emitted from biomass burning, J. Geophys. Res.-Atmos., 119, 12272-12286, doi:10.1002/2013JD021272, 2014.

Moosmüller, H., Chakrabarty, R. K., and Arnott, W. P.: Aerosol light absorption and its measurement: A review, J. Quant. Spectrosc. Ra., 110, 844-878, doi:10.1016/j.jqsrt.2009.02.035, 2009.

Nakayama, T., Ikeda, Y., Sawada, Y., Setoguchi, Y., Ogawa, S., Kawana, K., Mochida, M., Ikemori, F., Matsumoto, K., and Matsumi, Y.: Properties of light-absorbing aerosols in the Nagoya urban area, Japan, in August 2011 and January 2012: Contributions of brown carbon and lensing effect, J. Geophys. Res.-Atmos., 119, 12721-12739, doi:10.1002/2014JD021744, 2014.

NIOSH: Manual of Analytical Methods, Elemental carbon (diesel particulate): Method 5040, edited by: Eller, P. M. and Cassinelli, M. E., National Institute for Occupational Safety and Health, Cincinnati, OH, 1999.

Olson, M. R., Garcia, M. V., Robinson, M. A., Van Rooy, P., Dietenberger, M. A., Bergin, M., and Schauer, J. J.: Investigation of black and brown carbon multiple-wavelength- dependent light absorption from biomass and fossil fuel combustion source emissions, J. Geophys. Res.-Atmos., 120, 6682-6697, doi:10.1002/2014JD022970, 2015.

Page, S. E., Siegert, F., Rieley, J. O., Boehm, H.-D. V., Jaya, A., and Limin, S.: The amount of carbon released from peat and forest fires in Indonesia during 1997, Nature, 420, 61-65, doi:10.1038/nature01141, 2002.

Pokhrel, R. P., Wagner, N. L., Langridge, J. M., Lack, D. A., Jayarathne, T., Stone, E. A., Stockwell, C. E., Yokelson, R. J., and Murphy, S. M.: Parameterization of single-scattering albedo (SSA) and absorption Ångström exponent (AAE) with EC / OC for aerosol emissions from biomass burning, Atmos. Chem. Phys., 16, 9549-9561, doi:10.5194/acp-16-9549-2016, 2016.

Sakaeda, N., Wood, R., and Rasch, P. J.: Direct and semidirect aerosol effects of southern African biomass burning aerosol, J. Geophys. Res., 116, D12205, doi:10.1029/2010JD015540, 2011.

Saleh, R., Hennigan, C. J., McMeeking, G. R., Chuang, W. K., Robinson, E. S., Coe, H., Donahue, N. M., and Robinson, A. L.: Absorptivity of brown carbon in fresh and photo-chemically aged biomass-burning emissions, Atmos. Chem. Phys., 13, 76837693, doi:10.5194/acp-13-7683-2013, 2013.

Saleh, R., Robinson, E. S., Tkacik, D. S., Ahern, A. T., Liu, S., Aiken, A. C., Sullivan, R. C., Presto, A. A., Dubey, M. K., Yokelson, R. J., Donahue, N. M., and Robinson, A. L.: Brownness of organics in aerosols from biomass burning linked to their black carbon content, Nat. Geosci., 7, 647-650, doi:10.1038/ngeo2220, 2014.
Saleh, R., Marks, M., Heo, J., Adams, P. J., Donahue, N. M., and Robinson, A. L.: Contribution of brown carbon and lensing to the direct radiative effect of carbonaceous aerosols from biomass and biofuel burning emissions, J. Geophys. Res.-Atmos., 120, 10285-10296, doi:10.1002/2015JD023697, 2015.

Stockwell, C. E., Yokelson, R. J., Kreidenweis, S. M., Robinson, A. L., DeMott, P. J., Sullivan, R. C., Reardon, J., Ryan, K. C., Griffith, D. W. T., and Stevens, L.: Trace gas emissions from combustion of peat, crop residue, domestic biofuels, grasses, and other fuels: configuration and Fourier transform infrared (FTIR) component of the fourth Fire Lab at Missoula Experiment (FLAME4), Atmos. Chem. Phys., 14, 9727-9754, doi:10.5194/acp-149727-2014, 2014.

Stockwell, C. E., Jayarathne, T., Cochrane, M. A., Ryan, K. C., Putra, E. I., Saharjo, B. H., Nurhayati, A. D., Albar, I., Blake, D. R., Simpson, I. J., Stone, E. A., and Yokelson, R. J.: Field measurements of trace gases and aerosols emitted by peat fires in Central Kalimantan, Indonesia, during the 2015 El Niño, Atmos. Chem. Phys., 16, 11711-11732, doi:10.5194/acp-16-11711-2016, 2016.

Turpin, B. J., Huntzicker, J. J., and Hering, S. V.: Investigation of organic aerosol sampling artifacts in the Los-Angeles basin, Atmos. Environ., 28, 3061-3071, 1994.

Wang, X., Heald, C. L., Sedlacek, A. J., de Sá, S. S., Martin, S. T., Alexander, M. L., Watson, T. B., Aiken, A. C., Springston, S. R., and Artaxo, P.: Deriving brown carbon from multiwavelength absorption measurements: method and application to AERONET and Aethalometer observations, Atmos. Chem. Phys., 16, 1273312752, doi:10.5194/acp-16-12733-2016, 2016.

Ward, D. E. and Radke, L. F.: Emissions measurements from vegetation fires: A omparative evaluation of methods and results, in: Fire in the Environment: The Ecological, Atmospheric and Climatic Importance of Vegetation Fires, edited by: Crutzen, P. J. and Goldammer, J. G., John Wiley, New York, 53-76, 1993.

Washenfelder, R. A., Attwood, A. R., Brock, C. A., Guo, H., Xu, L., Weber, R. J., Ng, N. L., Allen, H. M., Ayres, B. R., Baumann, K., Cohen, R. C., Draper, D. C., Duffey, K. C., Edgerton, E., Fry, J. L., Hu, W. W., Jimenez, J. L., Palm, B. B., Romer, P., Stone, E. A., Wooldridge, P. J. and Brown, S. S.: Biomass burning dominates brown carbon absorption in the rural southeastern United States, Geophys. Res. Lett., 42, 653-664, doi:10.1002/2014GL062444, 2015.

Wehner, B., Philippin, S., Wiedensohler, A.: Design and calibration of a thermodenuder with an improved heating unit to measure the size-dependent volatile fraction of aerosol particles, J. Aerosol Sci., 33, 1087-1093, 2002.

Wiegand, J. R., Mathews, L. D., and Smith, G. D.: A UV-Vis Photoacoustic Spectrophotometer, Anal. Chem., 86, 6049-6056, doi:10.1021/ac501196u, 2014.

Yang, M., Howell, S. G., Zhuang, J., and Huebert, B. J.: Attribution of aerosol light absorption to black carbon, brown carbon, and dust in China - interpretations of atmospheric measurements during EAST-AIRE, Atmos. Chem. Phys., 9, 2035-2050, doi:10.5194/acp-9-2035-2009, 2009.

Yokelson, R. J., Ward, D. E., Susott, R. A., Reardon, J., and Griffith, D. W. T.: Emissions from smoldering combustion of biomass measured by open-path Fourier transform infrared spectroscopy, J. Geophys. Res., 102, 18865-18877, 1997. 
Yuan, J.-F., Huang, X.-F., Cao, L.-M., Cui, J., Zhu, Q., Huang, C.N., Lan, Z.-J., and He, L.-Y.: Light absorption of brown carbon aerosol in the PRD region of China, Atmos. Chem. Phys., 16, 1433-1443, doi:10.5194/acp-16-1433-2016, 2016.
Zhang, X., Lin, Y.-H., Surratt, J. D., and Weber, R. J.: Sources, Composition and Absorption Ångström Exponent of Lightabsorbing Organic Components in Aerosol Extracts from the Los Angeles Basin, Environ. Sci. Technol., 47, 3685-3693, doi:10.1021/es305047b, 2013. 